\title{
Immigration Regimes and Schooling Regimes: Which Countries Promote Successful Immigrant Incorporation?
}

\section{Citation}

Hochschild, Jennifer L. and Porsha Cropper. 2010. Immigration regimes and schooling regimes: which countries promote successful immigrant Incorporation? Theory and Research in Education 8(1): 21-61.

\section{Published Version}

doi:10.1177/1477878509356342

\section{Permanent link}

http://nrs.harvard.edu/urn-3:HUL.InstRepos:4265938

\section{Terms of Use}

This article was downloaded from Harvard University's DASH repository, and is made available under the terms and conditions applicable to Other Posted Material, as set forth at http:// nrs.harvard.edu/urn-3:HUL.InstRepos:dash.current.terms-of-use\#LAA

\section{Share Your Story}

The Harvard community has made this article openly available.

Please share how this access benefits you. Submit a story.

\section{Accessibility}




\title{
Immigration Regimes and Schooling Regimes: Which Countries Promote Successful Immigrant Incorporation?
}

\author{
Jennifer L. Hochschild \\ Harvard University, Government Department, and \\ Porsha Cropper \\ Harvard University, Government and Social Policy Ph.D. Program
}

August 3, 2009

Slightly revised, November 30, 2009

\begin{abstract}
While Canada is often described as the most and France as one of the least successful countries in the realm of immigrant incorporation, the question remains unresolved of how to evaluate a country's policies for dealing with immigration and incorporation relative to that of others. Our strategy is to examine the relationships among 1) countries' policies and practices with regard to admitting immigrants, 2) their educational policies for incorporating first and second generation immigrants, and 3) educational achievement of immigrants and their children. We compare eight western industrialized countries. We find that immigration regimes, educational regimes, and schooling outcomes are linked distinctively in each country. States that are liberal, or effective, on one dimension may be relatively conservative, or ineffective, on another, and countries vary in their willingness and ability to help disadvantaged people achieve upward mobility through immigration and schooling. We conclude that by some normative standards, France has a better immigration regime than does Canada. Overall, this study points to new ways to study immigration and new normative standards for judging states' policies of incorporation.
\end{abstract}

KEYWORDS: immigration regimes, educational regimes, immigrant incorporation, academic achievement, mobility, assimilation

\section{INTRODUCTION}

There would probably be no consensus even on the descriptive question of which countries exhibit more favorable environments for second-generational educational success. Clearly, it is highly desirable to move toward more standardized analyses with larger samples in order to establish the cross-national patterns (Heath et al. 2008): 227). 
That is our goal in this article. ${ }^{1}$ But we begin with a concrete example: Observers often depict Canada as the model for immigration policy and immigrant incorporation, at least in comparison with other wealthy industrialized countries. For several decades, federal and provincial governments have sought immigrants and welcomed them with an official policy of multiculturalism and institutions designed to help incorporate newcomers (Bloemraad 2006). An unusually high proportion of the public endorses increased or stable levels of immigration. ${ }^{2}$ Immigrants and their children are generally well educated and get good jobs, and relatively few live in isolated ghettos. Although Canada is not innocent of racism, it has a constitutional commitment to multiculturalism and many strong policies designed to foster mutual respect and minority empowerment.

In contrast, France is often seen as a model of how not to handle immigration and immigrants. For decades, immigrants were reluctantly admitted and encouraged to return home after completing their needed but ill-paid work. Naturalization laws are complicated; most immigrants' children born in France become citizens only at specified ages, with specified lengths of residency, and at parental request. France rejects official recognition of ethnicities or races in favor of shared republicanism; no matter how desirable as an ideology, the lack of systematic data makes it difficult to address painfully clear group-based disadvantage. A large share of immigrants and their descendents live in isolated, deeply poor communities with high crime rates, few jobs, and poor schooling. Descendents of immigrants rioted in 2005 to protest their exclusion from full membership in French society, but little has changed. Two-thirds of the French, compared with fewer than one-third of Canadians, would prefer less immigration.

We do not dispute these characterizations of Canada and France; too much evidence supports both. We do, however, want to complicate the picture of each society in two ways, by responding to the call in the epigraph above. We systematically compare eight western, ${ }^{3}$ industrialized states in terms of their immigration and citizenship regimes, educational regimes, and schooling outcomes for immigrants and their descendents. ${ }^{4}$ Locating Canada and France among other states permits a comparison that may affect one's evaluation of their (and other countries') strategies for dealing with immigration and incorporation. The comparison will at least provide an essential discipline for any discussion of feasible reforms.

In addition, we bring together the often separated topics of immigration policy and immigrant policy. ${ }^{5}$ There are several compelling reasons to do so. First, immigration and immigrant (non)incorporation are seamlessly linked in the lives of those individuals who move from one country to another or whose parents did so; artificially separating the two phenomena distorts any understanding of newcomers' actual circumstances. Second, in policy terms, a country's immigration policy will necessarily affect, though it will not determine, its incorporation policy. For example, a receiving country that encourages immigration of former colonial subjects faces a different, though not necessarily easier, set of issues with regard to assimilating them than does a country that encourages or permits immigration of people with no historical, linguistic, cultural, or community ties. ${ }^{6}$ Third, the politics of immigration and immigrant incorporation may be linked. If the native-born perceive immigrants to be of "high quality," however that is defined, they are more likely to welcome them into schools, neighborhoods, workplaces, 
and political organizations than if the country permits entry from people who are feared or despised.

Finally, one's normative position with regard to immigration is complicated by considering immigration and immigrant policy together. People on the left may be especially anxious for immigrants to be incorporated into receiving countries fully, respectfully, and without any hint of racism or second class citizenship. But that is most likely to occur when immigration policy has restricted entry to newcomers of the same ethnic background who bring with them considerable social, cultural, and financial capital. Such a restrictive immigration policy may seem unfair to those on the left (it certainly seems unfair to us). Conversely, people on the right may be especially anxious for immigrants to contribute economically, generally by taking low-paid or unpleasant jobs with few takers among the native born. But that is most likely to occur when immigration policy encourages deeply poor and often non-Anglo newcomers, who bring few resources to the host country except their ability and willingness to work hard for slight reward. That sort of immigration policy makes assimilation very difficult to accomplish - which may be of especial concern to those on the right.

Only by looking at both sides of the dynamic - who is permitted to enter and what happens after they enter - can a polity decide what combination of virtues and defects, or benefits and costs, to embrace. As our analysis below shows, the costs and benefits are not fixed; a state can do a good deal to enhance or undermine incorporation from any starting point in immigration policy. But who enters surely affects who becomes a fullfledged member of the receiving polity. And yet, immigration and immigrant regimes are too seldom considered together in academic (or political) discourse. This article brings them into direct contact, so that we can evaluate how well countries are handling migration issues broadly defined.

Given space constraints, we address only what is happening across our eight polities, saying little about why and how immigration and schooling regimes are linked. Answering those questions is, of course, essential, but temporally secondary. Only after we have achieved some clarity on what these countries are doing, which turns out to be surprisingly difficult, ${ }^{7}$ can we eventually pursue answers to why and how.

We conclude after this analysis that Canada does not look so good in its handling of migration, nor France so bad, as initial impressions suggest. More abstractly, immigration regimes and regimes for immigrants turn out to be linked in quite distinct ways. Countries that are liberal, or effective, on one dimension are relatively conservative, or ineffective, on the other. Demonstrating the varied relationships between immigration and immigrant regimes will, we hope, challenge common beliefs about policy bundles or political strategies and encourage deeper and clearer thinking about a phenomenon likely to shape the twenty-first century.

\section{Defining Terms and Choosing Cases}

An immigrant is narrowly incorporated in a host society if he or she can act effectively: supporting a family, being able to engage with the public arena, staying healthy enough to engage in daily activities, speaking the host country language well enough to communicate, acquiring enough contextual knowledge to negotiate daily exigencies. ${ }^{8} \mathrm{~A}$ more expansive definition of incorporation would include a sense that one's religious, cultural, and possibly nationality-based values and practices can be expressed in the host 
country without penalty or denigration, and that one can make some demands on the polity without fearing retribution or total failure. Most broadly understood, an immigrant or immigrant's child is incorporated when the fact of being foreign-born or -parented plays no explanatory role in one's life choices and trajectory. ${ }^{9}$ Thus immigrants could remain, or even become, poor or powerless and still be fully incorporated if a native-born person in the same circumstances might well have the same outcome.

Although immigrant incorporation has many facets, we focus only on schooling, especially school achievement as measured through test scores. Education is both a key indicator and a cause of other types of incorporation. As one author put it, France's assimilation policy is based on "the unifying function assigned to state institutions, and particularly the school, in the building and the reproduction of... citizenship" (Zanten 1997 ). Mutatis mutandis, one could say the same about most if not all western industrialized states.

Within the realm of education, we focus on scores on standardized achievement tests. Test scores are only one - and a highly controversial -- element of schooling. But they are potentially comparable across groups, time, and countries, and they are reasonably good predictors of success later in life (for example, see (Hedges and Nowell 1999). Roughly speaking, the higher one's test score, the better are one's chances for a good job, fluency in the host country's language, good health, effective social and political participation, and cultural engagement. Test scores, especially measured as relative change over time, are also a good indicator of how hard a host country is trying to incorporate newcomers. If a country educates all of its students fairly well or if it is improving in its capacity to educate those at the bottom of the test score distribution, it stands a good chance of succeeding in other incorporative efforts as well.

"Successful" incorporation requires a normative, not empirical, definition. Immigrants are better off, narrowly speaking, if they believe that their lives are improved compared with what would have happened had they stayed in the country of origin. ${ }^{10}$ The receiving society is better off, narrowly speaking, if its members believe that they gain more from immigration than they lose, and if enough members of the society perceive a positive balance so that immigration and immigrant policies are relatively persistent and stable. ${ }^{11}$ Defined broadly, success requires that enough immigrants and host-country residents are genuinely glad that the migration has occurred; it is a positive good, not just the lesser of various evils. For example, many Russian Jewish migrants to New York city, and most of their children, are thriving, while Dominican migrants and their children have found much less success (Kasinitz et al. 2008).

Why these eight states? Our goal was to examine enough wealthy industrialized countries to see a wide array of immigration and education regimes, while keeping the comparisons manageable. ${ }^{12}$ The main distinction is between Anglophone, chiefly settlerbased, states (United Kingdom, United States, Canada, and Australia) and continental European countries in which large-scale immigration is new. Within the latter group, France and Germany were obvious choices. Belgium and Switzerland provided representation from smaller states with recent intense politics around immigration. This set of states includes unitary and federal, large and small, Anglophone and nonAnglophone, welcoming and ambivalent, educationally rigid and fluid - and ultimately more and less successful - polities that are all wrestling with migration and its impact. 


\section{Immigration Regimes}

The eight countries vary in how many, and what kind of, migrants they admit? ${ }^{13}$ All have experienced immigration over the past decade, although at varied levels, as figure 1a and $1 \mathrm{~b}$ show. We provide two versions of figure 1; the second panel excludes the United States so that variation among the other cases is easier to see.

Figure 1a. Inflows of Foreign Population into Selected OECD Countries, 1996-2006 (including the United States)

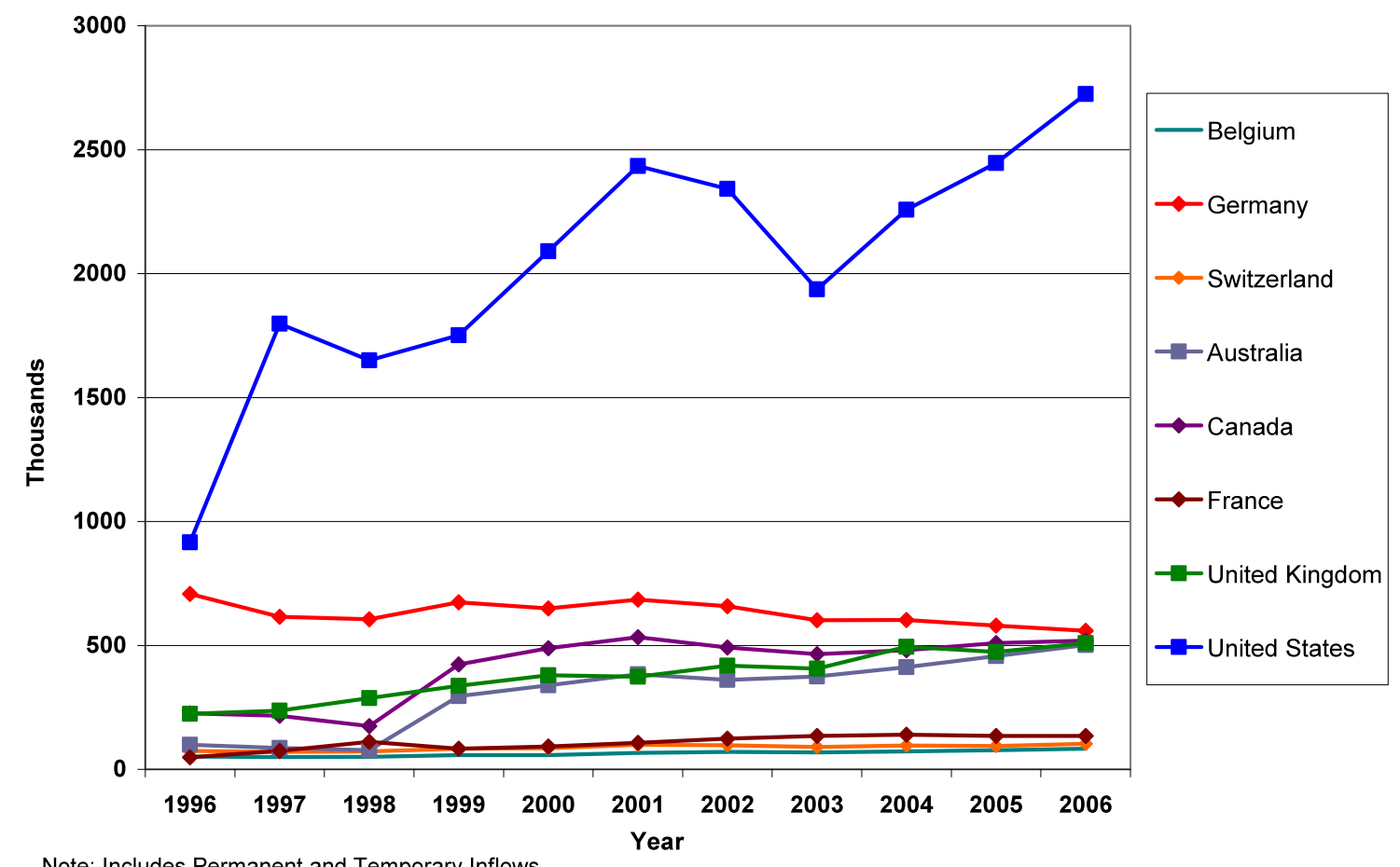

Source:(Organisation for Economic Co-operation and Development 2007c, 2008c): Table A.1.1

Figure 1b. Inflows of Foreign Population into Selected OECD Countries, 1996-2006 (excluding the United States) 


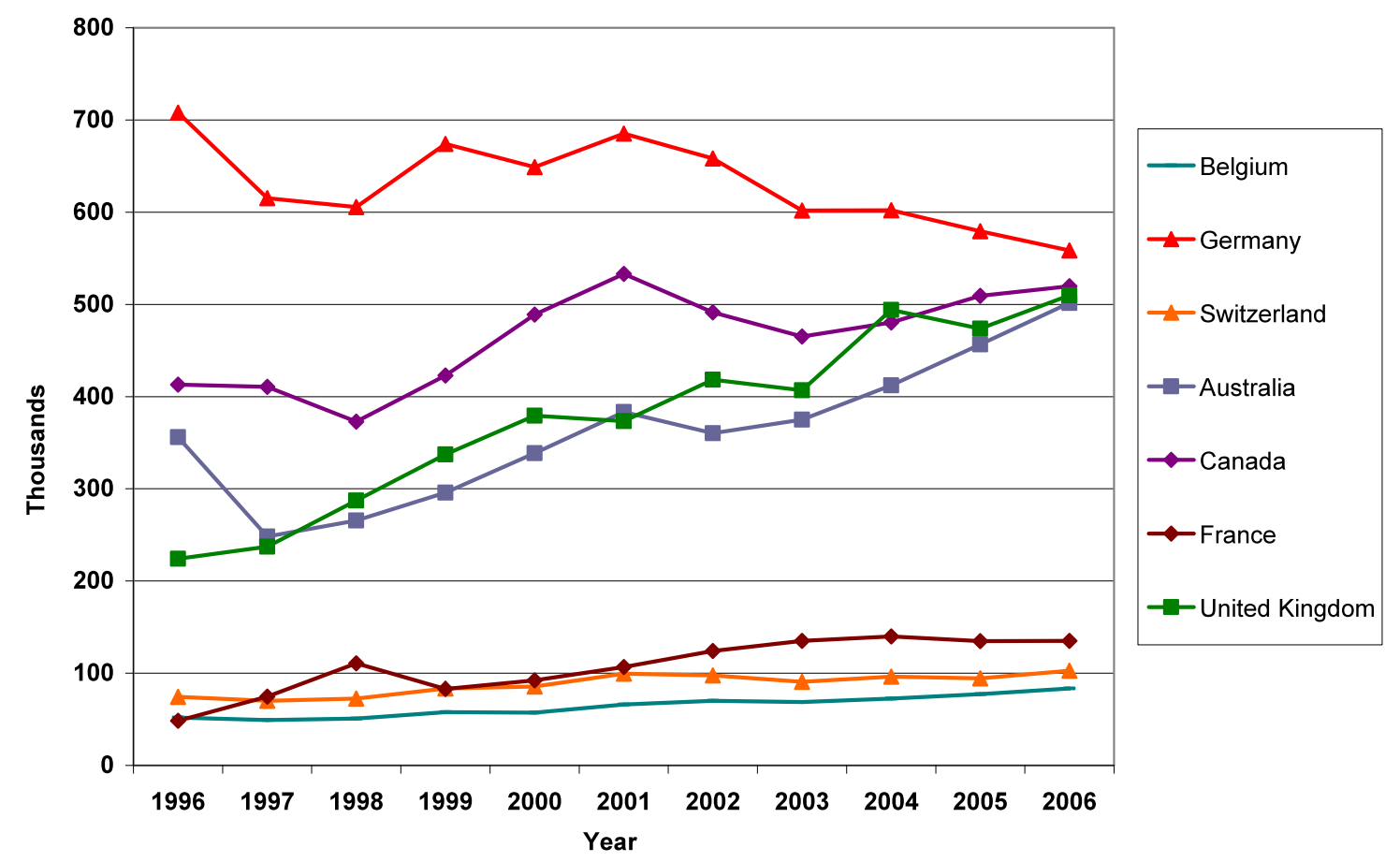

Note: Includes Permanent and Temporary Inflows

Source: (Organisation for Economic Co-operation and Development 2007c, 2008c): Table A.1.1

Figure 1a shows that the number of migrants per year skyrocketed in the United States after 1996, increasing the gap between it and the rest of our eight states. As Figure 1b shows more clearly, migrant flows have declined slightly in Germany, and increased slightly in the United Kingdom, Canada, and Australia, thus diminishing the disparities among four of the seven states. By 2006, we see three clusters in terms of the absolute number of migrants: few (Switzerland, France, and Belgium), some (Germany, UK, Canada, and Australia), and many (US). (Migration has declined with the recent economic downturn, but these basic patterns have not changed. $)^{14}$

As a proportion of the state's population, the pattern is different. As of 2005 (the most recent years with comparable OECD data), almost a quarter of the population in Australia and Switzerland were foreign-born. They were followed by Canada (19 percent), Germany and the US (13 percent each), the UK (10 percent), Belgium ( 9 percent), and finally France ( 8 percent) The foreign-born share of the state's total population has remained about the same since 1995 in Australia and Belgium, has grown somewhat in Canada and France (becoming about two percent more of the population), and has grown substantially in Germany, Switzerland, the US and the UK (becoming 4 to 6 percent more of the population). ${ }^{15}$ In short, each of these countries shows a different combination of absolute numbers, population proportions, and change over time in numbers and proportions. The politics and policies around migration and incorporation can likewise be expected to differ.

Migrants' Legal Status: Of course, not all migrants have the same political status or evoke the same response from the host country, so one must quickly move beyond raw 
numbers. The most crucial political distinction among migrants is between legal and illegal entry. In the aggregate, the share of immigrants who are undocumented affects labor markets, the political valence of immigration, law enforcement, educational opportunities, electoral representation, and other mechanisms of incorporation. For an individual, legal status dramatically affects one's capacity to become incorporated, with impacts lasting across generations (Bean et al. 2006).

So far as we can tell from very inaccurate estimates, countries vary greatly in their number and proportion of undocumented immigrants. As of 2008, the United States had up to 12 million undocumented migrants, almost 4 percent of the total population and about 30 percent of the foreign-born (Passel and Cohn 2008). According to one estimate, perhaps a quarter of the foreign-born in the UK are "irregular migrants." Comparable figures for our other states are 17 percent in Belgium, 14 percent in Germany, 10 percent in Switzerland, 6 percent in France, 3 percent in Canada, and 1 percent in Australia [(Mansoor and Quillan 2006); (Papademetriou 2005); authors' calculations from http://dx.doi.org/10.1787/828518448448; (Organisation for Economic Co-operation and Development 2006a): 46).

Flows of illegal migrants probably vary across years more than do flows of legal migrants, depending on the condition of a receiving country's economy and labor market, the rise and fall of punitive or regulatory regimes, and the situation in the home country (Papademetriou and Terrazas 2009). Most illegal migrants are young adults, disproportionately male and childless (at least in the host country). They are less likely than legal immigrants to be in school in the host country. All of this points to the fact that the process of incorporation of the undocumented is probably very different than that of legal immigrants. Both for that reason and because we simply do not have the evidence needed to analyze them carefully, the rest of this article focuses on legal immigrants or on "immigrants" in general.

Status of Legal Migrants: Legal immigrants themselves have particular statuses, which imply different receptions in a host country and different capacities for successful incorporation. Figure 2 shows the variation across our eight states in immigration statuses for legal permanent migrants, again for the most recent year available, 2006.

Figure 2: Migration Inflows by Legal Status in Selected Countries, 2006 


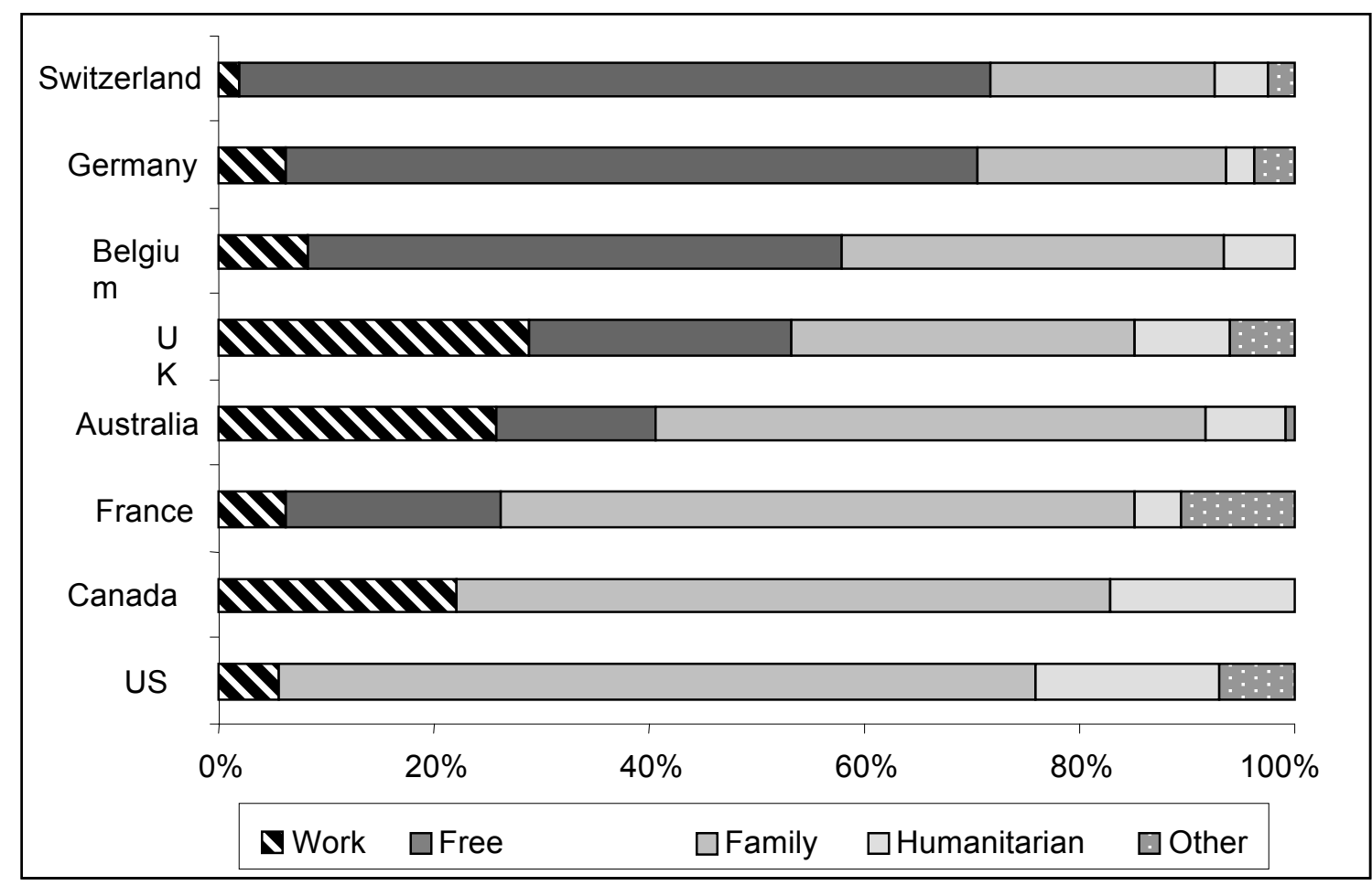

Source: authors' revision of (Organisation for Economic Co-operation and Development 2008b), p. 38

Roughly speaking, we can separate immigrant slots into two categories: those intended mainly to benefit the native-borns and host country through admission of generic workers (the first two bars - work and free movement), and those intended primarily to benefit immigrants through admission of particular individuals (the third and fourth bars - family and humanitarian). Both groups can become incorporated, but we assume here that immigrants who bring desired high-skilled labor into a country have the greatest chance for full incorporation.

Clearly these eight states are setting different policies for the kinds of immigrants they seek or permit. Almost three-quarters of legal immigrants into Switzerland and Germany in 2006 came to work, ${ }^{16}$ whereas over three-quarters of legal immigrants into Canada and especially into the United States came to join their families or as asylees or refugees. ${ }^{17}$

If one looks at the amount of effort states make to attract the immigrants they want, the pattern looks a bit different. Australia, Canada, and the UK gave the most incentives to attract permanent skilled workers in the early 2000s, whereas the US gave the fewest (Lowell 2005). Germany had no program at all for permanent skilled worker immigration; Switzerland, France, and Belgium were in the middle of this index. Programs to attract temporary high-skilled workers as of 2004 were similarly ranked; among our states the UK and Australia were the most encouraging, and Germany the least. (Belgium and Switzerland were not ranked in this analysis) ${ }^{18}[($ Lowell 2005; see also (Cerna 2008)). 
Immigrants' Educational and Occupational Level: Whatever their legal status, once immigrants have entered a host country, incorporation can, in theory, begin. How successful it will be partly depends on the newcomers' educational level. Figure 3 compares levels of education of foreign-born and native-born adults in 2003-04, at two levels of education. The first panel focuses on tertiary or college-level education, and the second on less than secondary schooling. Both figures are arrayed so that as one moves down the panel, one moves from immigrant advantage to immigrant disadvantage relative to native-borns.

Figure 3a: Tertiary Education of Foreign- and Native-Born Populations, Aged 25 to 54, in Selected Countries, 2003-2004

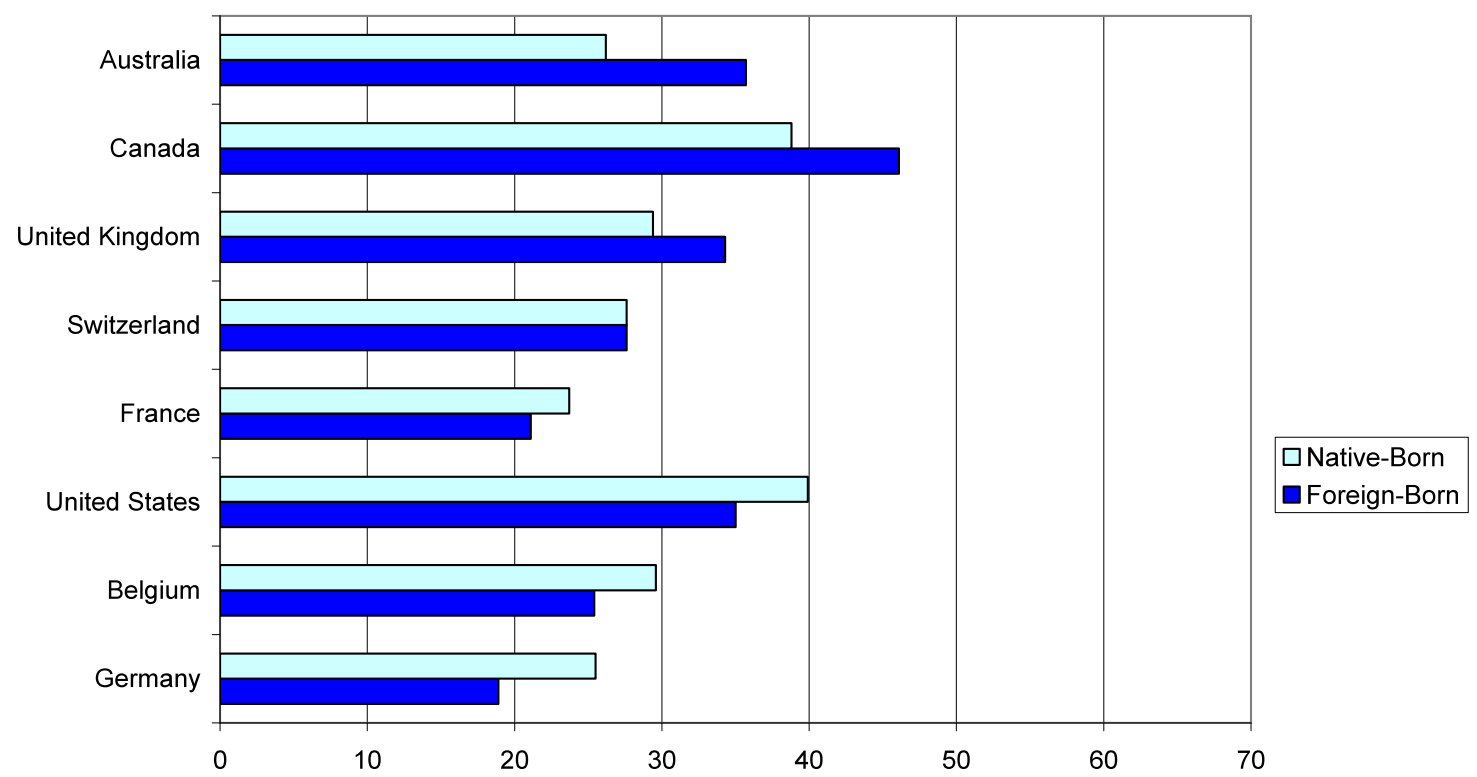

Note: Countries are ordered from greatest pro-immigrant disparity to greatest pro-native disparity

Source: European Countries: European union Labor Force Survey (data provided by Eurostat); United States: Current Population Survey March Supplement; Australia: Survey of Household, Income, and Labour Dynamics Canada: Population Censuses

Figure 3b: Primary Education of Foreign- and Native-Born Populations, Aged 25 to 54, in Selected Countries, 2003-2004 


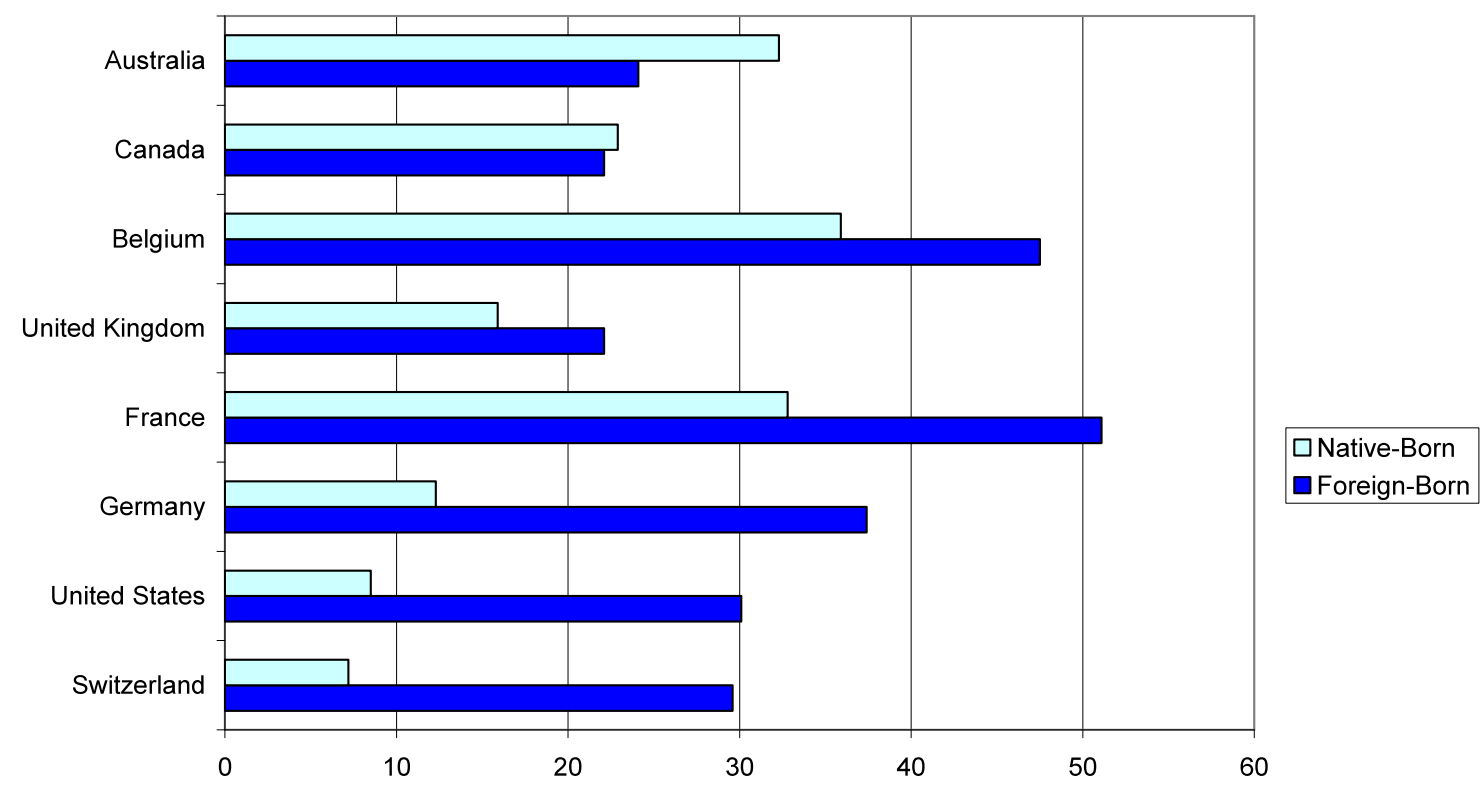

Note: Countries are ordered from greatest pro-immigrant disparity to greatest pro-native disparity

Source: European Countries: European union Labor Force Survey (data provided by Eurostat); United States: Current Population Survey March Supplement; Australia: Survey of Household, Income, and Labour Dynamics; Canada: Population Censuses

Immigrants show a bimodal distribution of educational levels in many countries, corresponding to the several tracks of the country's immigration regime. A higher proportion of immigrants than of native-borns in Canada, Australia, and the UK have tertiary degrees (college or higher) — to be expected in countries that actively seek or disproportionately permit to enter high-skilled workers. Conversely, in the United States, Switzerland, France, and Germany, a much higher proportion of immigrants than of native-borns have only a primary level of education - also to be expected in countries that have not recruited high-skilled workers, that have a long history of low-skilled guest workers programs, or that have a high share of immigrants entering illegally, through family reunification or via humanitarian programs.

A similar array emerges, not surprisingly, if one looks at the occupations of native- and foreign-borns. More immigrant than native-born men are professionals in Australia, Belgium, Canada, France, and the UK; the reverse obtains for Switzerland and Germany (data are not available for the US) [(Organisation for Economic Co-operation and Development 2008d): table 6.1]. That accords with the evidence on educational levels in figure 3 for all countries except France.

One can already begin to see complications in the portrayals of France and Canada with which this chapter started. For decades, Canada has sought and attained permanent immigrants with high levels of education and job skills. By now, even its extensive family reunification policies yield a relatively high-status immigrant population. Thus as of 2001 it ranked the second highest (after Australia) of our eight states in an index of immigrant education, whether measured relatively or absolutely (Lowell 2005). That is a comparatively easy population to approve of, and to incorporate into one's society. 
France, conversely, has admitted primarily immigrants with low levels of education and qualifications only as low-wage laborers. It has recently sought to appeal to high-skilled workers, but as of 2001 it ranked the lowest of our eight states in the index of immigrant education (Lowell 2005). That is a comparatively easy population to disapprove of, and a hard group to incorporate into one's society. The full story of the connections among immigration regimes, immigrants, and incorporative policy is much more complicated, of course, but a good starting point is to note that a country's immigration regime may be closely connected with its subsequent ease in incorporating its immigrant population.

Contextual Knowledge: Immigrants also vary in their knowledge of the environment into which they are moving. Knowing the host country's language facilitates incorporation, no matter how broadly defined, since it greatly facilitates one's capacity to succeed in all other domains of life (Euwals 2007; Hansen 2008). Broader knowledge of the society is also associated with immigrants' ability to foster their children's schooling (Heath et al. 2008) and presumably to achieve other goals as well.

A state's choice of immigration regimes can considerably affect the proportion of newcomers who bring these forms of social capital with them. English language ability (and French, in Canada) is part of the point system for high-skilled workers in Canada, the UK, and Australia. Some countries encourage residents of former colonies or descendents of host-country nationals to "come home;" those people have backgrounds that make them relatively familiar with their new homes, even if their relationship with the "home" country is psychologically complex. Conversely, some countries welcome or permit people from very different backgrounds to immigrate.

Table 1 shows the variation in the likelihood of contextual knowledge among immigrants for our eight countries. It includes two measures: the share of the foreignborn population in each state from the countries of origin sending the largest number of immigrants (the stock), and the average annual immigration from 1995 to 2005 from the five most significant sending countries (the flow). ${ }^{19}$ These two measures overlap substantially but not completely.

Table 1: Countries of Birth of Foreign-Born Population in Selected Countries, 1995 to 2006

\begin{tabular}{|l|l|l|c|}
\hline Country & $\begin{array}{l}\text { Countries of birth of largest } \\
\text { number of immigrants }\end{array}$ & $\begin{array}{l}\text { \% of foreign-born } \\
\text { population }\end{array}$ & $\begin{array}{l}\text { \% of total inflow, } \\
\text { annual average for } \\
1995-2005\end{array}$ \\
\hline \multirow{5}{*}{ Australia } & UK & $(2005) 23.6 \%$ & $12.5 \%$ \\
& New Zealand & 9.4 & 13 \\
& Italy & 4.6 & -- \\
& China & 4.0 & 8.0 \\
& Vietnam & 3.7 & -- \\
& India & 2.9 & 5.5 \\
& South Africa & 2.4 & 5.0 \\
\hline \multirow{5}{*}{ Belgium } & France & $(2005) \quad 12.3$ & 13 \\
& Morocco & 11.7 & 10 \\
& Italy & 9.9 & 4.0 \\
& Netherlands & 8.8 & 12 \\
& Turkey & 6.6 & 4.5 \\
& Germany & 6.6 & 5.0 \\
\hline
\end{tabular}




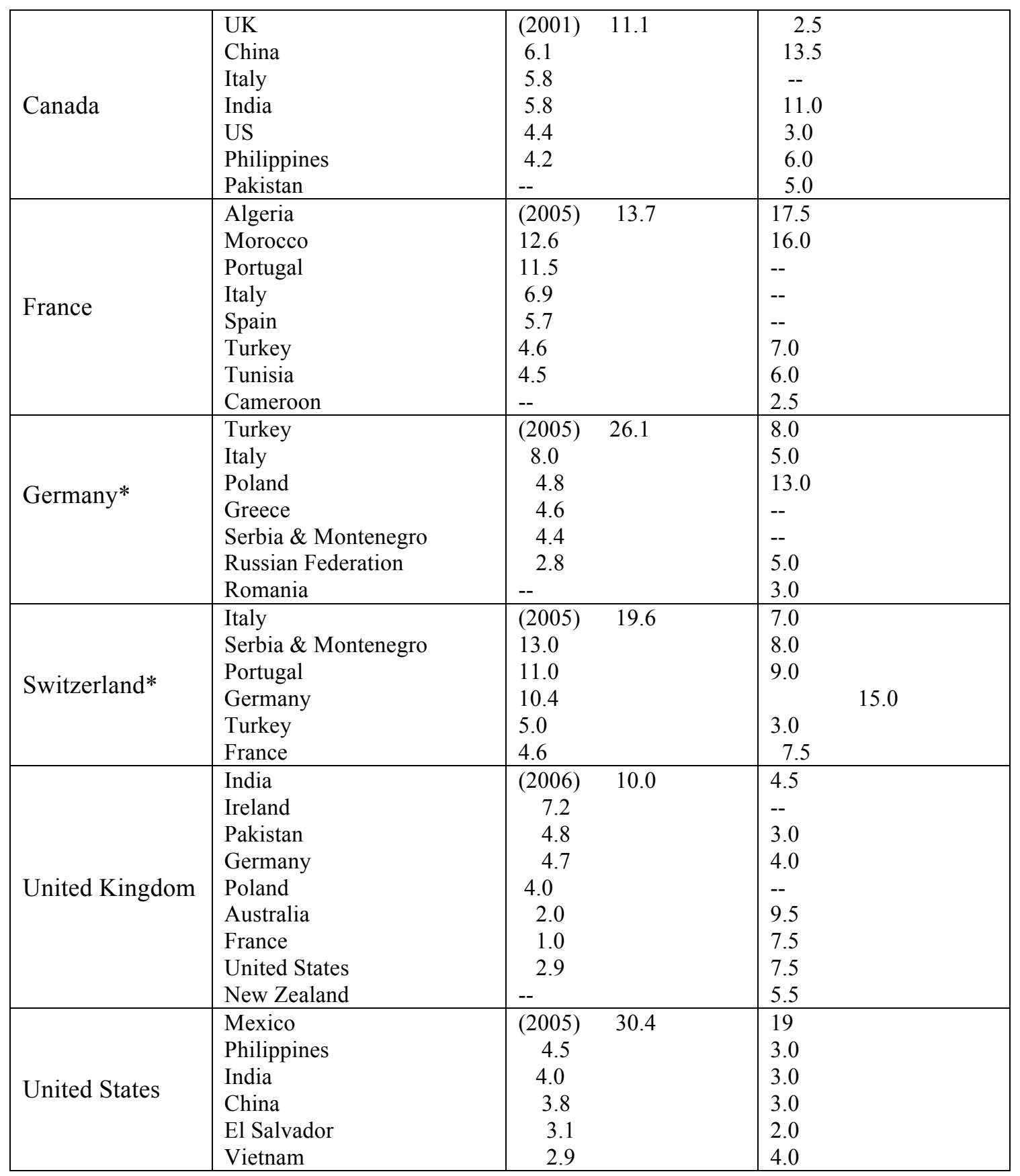

Sources: column 3:(Organisation for Economic Co-operation and Development 2007a): Tables B.1.4, B.1.5. Column 4:(Organisation for Economic Co-operation and Development 2008c), pp. $42-43$

* Stocks of foreign population, not foreign-born, in column 3.

Judging solely by country of birth, some host countries will have a much easier time incorporating their immigrants than will others. Column 3 shows that fully a third of Australia's and Switzerland's foreign-born populations, and close to a quarter of those in Belgium and the UK, are native speakers of the host country's language. In contrast, none of the largest groups of foreign-born populations in France, Germany, or the US are. Column 4 shows the same advantage for recent migrants to Australia, Belgium, 
Switzerland, and the UK, and the same linguistic disadvantage for recent migrants to France, Germany, and the US. Only Canada shows a shift from a linguistically somewhat advantaged stock to a linguistically somewhat disadvantaged flow (as migration has shifted from the UK to China).

Citizenship Regimes: Individuals choose whether to become citizens of the receiving country, but only within a set of constraining or motivating rules [(Bauböck 2006); (Minkenberg 2003); (Klusmeyer and Aleinikoff 2002); (Koopmans et al. 2005)]. Citizens are in a better position to become both narrowly and broadly incorporated (Howard 2006); for example, some states restrict public service employment to its citizens. So citizenship rules are a crucial link between immigration and integration regimes. Those rules vary across our eight cases, as does the proportion of foreign-born citizens. One citizenship policy index for the 1980s includes four of our eight cases. Belgium, France, and the UK had liberal rules; Germany was restrictive, as it had been since World War II on the grounds that it was "not an immigration country." 20 However, Germany recently liberalized its citizenship laws, earning a "moderate" ranking by 2000 (Howard 2006). From another study, we can add the United States and Canada as liberal, and Australia as moderate (by these criteria, the UK is moderately restrictive) (Hansen 2008). ${ }^{21}$ Switzerland remains consistently the most restrictive; it has no birthright citizenship, generally requires twelve years of residency and accomplishment of other benchmarks, and includes a decision by local authorities about a person's suitability to be a citizen of that locality. Voters defeated referenda to liberalize this regime several times in the past few decades, most recently in 2004 [(Helbling 2008); (D'Amato 2009)].

The British Council's Migrant Integration Policy Index (MIPEX) has developed a 6-item index of "access to nationality" for legal immigrants and their families. By this measure, Belgium and Canada have the most welcoming rules for access to nationality, averaging 2.5 each; France and the UK are close behind at 2.3 and 2.2 respectively; and Germany and Switzerland are least welcoming, at 2 and 1.7 respectively. [http://www.integrationindex.eu/ ] Our own calculations (using the 4 indicators identified) place the US at 2.75 and Australia at 3 - making them the most accessible [(Weil 2001); http://www.citizenship.gov.au/applying/spouses.htm].

As a result of these laws and their own situation or preferences, immigrants vary across countries in their likelihood of naturalizing. As of roughly 2000, only one tenth of foreign born residents of Switzerland were Swiss citizens, in sharp contrast to the threequarters of immigrants into Canada who had become citizens. In between lay Germany (29 percent), Belgium (41 percent), the US (48 percent), France (53 percent), and Australia (68 percent). ${ }^{22}$

\section{Arraying Countries by Conditions for Successful Incorporation}

We have now identified many of the key elements of immigration and membership regimes - legal status at entry, citizenship laws, education, knowledge of the host language, and cultural capital. Some of these indicators are themselves results of multiitem indices, and others could certainly be added. But the basic elements are in place for a robust index of the conditions for successful incorporation. The index enables us to array states along a continuum of, in effect, how difficult a task they have set for themselves in seeking to turn newcomers into "us." 
Appendix Table A1 scores the eight states on the twelve components of the index. Countries are awarded scores of 3 (high), 2 (medium), or 1 (low) points. High scores imply favorable conditions for successful incorporation of adult immigrants; low scores imply relatively or absolutely unfavorable conditions. Given the absence of any compelling causal theory of incorporation indicating that some criteria should matter more than others, we treat each element as independent and equal.

The results in Appendix Table A1 are summarized in table 2, which arrays the countries from the most to the least favorable conditions for successful incorporation:

Table 2: Scale of Conditions for Successful Incorporation in Selected Countries, c. 2005

\begin{tabular}{|l|c|c|c|c|}
\hline & $\begin{array}{l}\text { Score on index of } \\
\text { conditions for } \\
\text { successful } \\
\text { incorporation }\end{array}$ & $\begin{array}{l}\text { Number of 3's } \\
\text { (favorable } \\
\text { conditions for } \\
\text { incorporation) }\end{array}$ & $\begin{array}{l}\text { Number of 1's } \\
\text { (unfavorable } \\
\text { conditions for } \\
\text { incorporation) }\end{array}$ & $\begin{array}{l}\text { Number of items } \\
\text { for which the } \\
\text { country could } \\
\text { not be scored }\end{array}$ \\
\hline Australia & 34 & 10 & 0 & 0 \\
\hline UK & 30 & 7 & 1 & 1 \\
\hline Canada & 29 & 7 & 2 & 0 \\
\hline Belgium & 27 & 4 & 1 & 2 \\
\hline France & 24 & 3 & 3 & 0 \\
\hline Switzerland & 22 & 3 & 5 & 2 \\
\hline US & 19 & 2 & 7 & 1 \\
\hline Germany & 16 & 1 & 9 & 0 \\
\hline
\end{tabular}

NOTE: We examined 12 elements on a scale of 1 to 3 , so possible scores range from 12 to 36 . A country with missing data for an element was scored at 2 , in order to neither advantage nor disadvantage states on that element.

Source: Appendix Table A1.

Australia, Canada, and the UK have established immigration regimes and immigrant flows that make it relatively easy for newcomers to be at least narrowly incorporated into their societies. Conversely, Switzerland, Germany and the US have - intentionally or not - done the opposite. France and Belgium present a mixed picture, for quite different reasons.

We turn next to the same exercise of building an index, now focusing on schooling regimes. The goal is similar: to array countries along a continuum of the degree to which they foster young newcomers' ability to become incorporated. We focus on education both because comparable data are available and because schooling is the main vehicle for children's successful assimilation.

\section{Educational Regimes}

Once a state recognizes that immigrants and their children are not going "home" soon, it must decide how and how much schooling to provide. Schools and systems vary in their ability and willingness to educate all students, but this article sets practice aside in order to focus on policies to promote educational achievement. We assume that, as with immigration regimes, a democratic polity's laws and rules for schools roughly reflect its 
citizens' goals and commitments. We turn, then, to an examination of those laws and rules.

School Expenditures: A necessary, though hardly sufficient, element of any schooling regime is funding. The relationship is much looser than anyone would prefer (Burtless 1996), but roughly speaking the more a state spends on schooling, the higher the level of student achievement - or at least that is what one hopes. Our eight states vary in their levels and trajectories of spending on schools, as table 3 shows:

Table 3: School Spending for Selected Countries, c. 2005

\begin{tabular}{|c|c|c|c|c|c|c|c|}
\hline & \multicolumn{3}{|c|}{$\begin{array}{l}\text { Annual expenditure per } \\
\text { student for all services, } 2005\end{array}$} & \multirow{2}{*}{$\begin{array}{l}\text { Change in } \\
\text { expenditure on } \\
\text { schools, } 1995- \\
2005 \text { (primary } \\
\text { through post- } \\
\text { secondary, non- } \\
\text { tertiary) } \\
(2000=100)\end{array}$} & \multicolumn{3}{|c|}{$\begin{array}{l}\text { Annual expenditure per student } \\
\text { for all services, relative to GDP } \\
\text { per capita, } 2005\end{array}$} \\
\hline & $\begin{array}{l}\text { Pre- } \\
\text { primary }\end{array}$ & Primary & $\begin{array}{l}\text { Second } \\
\text { ary }\end{array}$ & & $\begin{array}{l}\text { Pre- } \\
\text { primary }\end{array}$ & Primary & $\begin{array}{l}\text { Seconda } \\
r y\end{array}$ \\
\hline Australia & -- & $\$ 6000$ & 8400 & 74 to 113 & -- & 18 & 25 \\
\hline Belgium & 4800 & 6600 & 7700 & $\mathrm{xx}$ to 107 & 15 & 21 & 24 \\
\hline Canada & -- & -- & $\begin{array}{c}7800 \\
(2004)\end{array}$ & $\begin{array}{c}106 \text { to } 116 \\
(2004)\end{array}$ & -- & -- & $\begin{array}{c}24 \\
(2004)\end{array}$ \\
\hline France & 4800 & 5400 & 8900 & 90 to 101 & 16 & 18 & 30 \\
\hline Germany & 5500 & 5000 & 7600 & 94 to 99 & 18 & 16 & 25 \\
\hline Switzerland & $3900 *$ & $8500 *$ & $12,900 *$ & 101 to $110^{*} \#$ & 11 & 24 & 36 \\
\hline UK & 6400 & 6400 & 7200 & 87 to 140 & 20 & 20 & 23 \\
\hline US & 8300 & 9200 & 10,400 & 80 to 108 & 20 & 22 & 25 \\
\hline
\end{tabular}

*public institutions only

\# public expenditures only

Source: (Organisation for Economic Co-operation and Development 2008a), chapter B.

The countries vary. The US spends about twice as much per capita as Switzerland on pre-primary, but less on secondary, schooling. Australia and the UK substantially increased their expenditures on schooling from 1995 to 2005, but they ended up differently, since the UK now proportionally outspends all other countries by a wide margin, whereas Australia sits in the middle of the pack.

Of course, national expenditures encompass immigrant, second generation, and native children alike, so they only begin to inform us of the schooling regime for incorporating newcomers. We turn, thus, to more fine-grained indicators of policies for educational incorporation.

Selection Criteria: Some schools and systems offer many second chances for students who initially struggle, while others use stringent rules to direct students into distinct channels. Some schools and systems have strong supply-side selection criteria, while others rely more on parental demand or less explicit selection criteria such as geographic districting. Table 4 presents various decision rules by which students select, or are selected into, their location in a country's schooling regime. The table focuses only on 
elements that most experts see as sorting mechanisms, making educational outcomes less equal or random than if that element did not obtain. ${ }^{23}$

Table 4: Principals' Report of Selection Criteria for Schools or School Systems in Selected Countries, c. 2006

\begin{tabular}{|c|c|c|c|c|c|c|}
\hline & \multirow{2}{*}{$\begin{array}{l}\text { First age } \\
\text { of } \\
\text { selection } \\
\text { in school } \\
\text { system }\end{array}$} & \multicolumn{4}{|c|}{$\begin{array}{l}\% \text { of students in schools where the following is } \\
\text { prerequisite or high priority for admission to the } \\
\text { school }\end{array}$} & \multirow{2}{*}{$\begin{array}{l}\text { \% of students } \\
\text { in school with } \\
\text { ability } \\
\text { grouping in all } \\
\text { subjects }\end{array}$} \\
\hline & & $\begin{array}{l}\text { Student's } \\
\text { academic } \\
\text { record }\end{array}$ & $\begin{array}{l}\text { Recommen- } \\
\text { dation of } \\
\text { feeder } \\
\text { school }\end{array}$ & $\begin{array}{l}\text { Parents } \\
\text { endorse } \\
\text { religious or } \\
\text { instructional } \\
\text { philosophy } \\
\text { of school }\end{array}$ & $\begin{array}{l}\text { Other } \\
\text { family } \\
\text { members } \\
\text { attend the } \\
\text { school }\end{array}$ & \\
\hline Australia & 16 & 9 & 18 & 27 & 42 & 5 \\
\hline Belgium & 12 & 26 & 7 & 40 & 10 & 22 \\
\hline Canada & 16 & 10 & 22 & 15 & 26 & 15 \\
\hline France & -- & -- & -- & -- & -- & -- \\
\hline Germany & 10 & 39 & 38 & 11 & 17 & 11 \\
\hline Switzerland & 12 & 51 & 40 & 2 & 2 & 40 \\
\hline UK & 16 & 10 & 7 & 12 & 33 & 8 \\
\hline US & 16 & 8 & 9 & 5 & 10 & 7 \\
\hline
\end{tabular}

Sources: (Organisation for Economic Co-operation and Development 2007b); (Organisation for Economic Co-operation and Development 2007c)

Again, countries vary. Switzerland has the most stringent formal policies - early age of selection, high proportion of schools with ability grouping, and high proportion of placements that depend on past achievement. Australia may have the most stringent informal policies, in the sense that many schools select according to parents' views or the siblings' attendance. German school tracks select participants very early, which disadvantages newcomers [although Table 4 does not reflect Germany's unique system of apprenticeship that works well for many immigrants, or at least their children (Crul and Schneider 2005)].

Like funding policies, selection criteria seldom focus directly on immigrant or minority status. However, the final element in our educational regime index does, since the students who need language training are likely to be disproportionately immigrants or their children.

Language Policy: All of these eight countries (or regions within them in some cases), have policies to foster acquisition of the host-country language. Table 5 shows the range of policies and the rough proportions of immigrant students in each type of program:

Table 5: Language Policy for Immigrant Students in Primary and Lower Secondary Education, Selected Countries, 2003 


\begin{tabular}{|c|c|c|c|c|c|c|c|c|}
\hline & \multicolumn{2}{|c|}{$\begin{array}{l}\text { language of } \\
\text { instruction }\end{array}$} & \multicolumn{2}{|c|}{$\begin{array}{l}\text { systematic language } \\
\text { support in language } \\
\text { of instruction }\end{array}$} & \multicolumn{2}{|c|}{$\begin{array}{l}\text { preparatory phase } \\
\text { in language of } \\
\text { instruction }\end{array}$} & \multicolumn{2}{|c|}{$\begin{array}{l}\text { bilingual } \\
\text { education, or } \\
\text { maintenance } \\
\text { bilingual education }\end{array}$} \\
\hline & Primary & $\begin{array}{l}\text { Lower } \\
\text { secondary }\end{array}$ & Primary & $\begin{array}{l}\text { Lower } \\
\text { secondary }\end{array}$ & Primary & $\begin{array}{l}\text { Lower } \\
\text { secondary }\end{array}$ & Primary & $\begin{array}{l}\text { Lower } \\
\text { secondary }\end{array}$ \\
\hline Australia* & $5-19 \%$ & $0->80 \%$ & $\begin{array}{c}35- \\
80 \%\end{array}$ & $0-80 \%$ & $0-64 \%$ & $0->80 \%$ & $0-10 \%$ & 0 \\
\hline $\begin{array}{l}\text { Belgium } \\
\text { (French } \\
\text { community } \\
\text { only) }\end{array}$ & $>80$ & $>80$ & 0 & 0 & $<5$ & $<5$ & 0 & $<5$ \\
\hline Canada* & -- & 0 & $35-80$ & $65-80$ & -- & $0-64$ & 0 & 0 \\
\hline France & -- & -- & -- & -- & -- & -- & -- & -- \\
\hline Germany & $5-19$ & $>80$ & $50-80$ & $5-19$ & $<5$ & $<5$ & $<5$ & 0 \\
\hline Switzerland* & $0-34$ & $<5-80$ & $20->80$ & $20-80$ & $<5$ & $<5$ & 0 & 0 \\
\hline UK & 0 & 0 & $>80$ & $>80$ & 0 & 0 & 0 & 0 \\
\hline
\end{tabular}

* varies by region of the country

Source: ((Organisation for Economic Co-operation and Development 2006b): chap. 5.) No comparable data are available for the US.

Table 5 is hard to interpret, since policies vary not only by country but also by region, district, school grade level, and recency of immigration. Arguably, in fact, language policies vary at least as much within a state as across them. Nevertheless, language policies can be added to the index of educational regimes by taking the midpoint in each range, separately for primary and for lower secondary grade levels - recognizing that this indicator is more than usually noisy.

\section{Arraying Countries by Schooling Accessibility for Young Newcomers}

We can now construct an index of educational accessibility for newcomers. Appendix Table A2 locates the eight countries on a seventeen-item index, ranging as before from 3 (most accessible) to 1 (least accessible). Table 6 shows the results; it is analogous to table 2, the index of immigration regimes. The table ranges from the countries with the most to those with the least accessible schooling regimes for newcomers:

Table 6: Scale of Educational Accessibility for Newcomers in Selected Countries, c. 2005

\begin{tabular}{|l|c|c|c|c|}
\hline & $\begin{array}{l}\text { Score on index of } \\
\text { schooling } \\
\text { accessibility for } \\
\text { newcomers }\end{array}$ & $\begin{array}{l}\text { Number of 3's } \\
\text { (high level of } \\
\text { accessibility) }\end{array}$ & $\begin{array}{l}\text { Number of 1's } \\
\text { (low level of } \\
\text { accessibility) }\end{array}$ & $\begin{array}{l}\text { Number of } \\
\text { items not } \\
\text { scored }\end{array}$ \\
\hline US & 44 & 11 & 1 & 3 \\
\hline UK & 39 & 8 & 3 & 0 \\
\hline Canada & 35 & 4 & 3 & 4 \\
\hline Australia & 35 & 5 & 4 & 3 \\
\hline Switzerland & 33 & 6 & 7 & 0 \\
\hline France & 31 & 2 & 5 & 8 \\
\hline Belgium & 28 & 2 & 8 & 1 \\
\hline
\end{tabular}




\begin{tabular}{|l|l|l|l|l|}
\hline Germany & 26 & 1 & 9 & 0 \\
\hline
\end{tabular}

NOTE: We examined 17 elements on a scale of 1 to 3 , so possible scores range from 17 to 51 . A country with missing data for a given element was scored at 2.

Source: Appendix Table A2

As before, this analysis would benefit from refinement, but it is highly suggestive. The United States received the highest score - reinforcing the old image of American exceptionalism, in which schooling rather than social welfare policy is the preferred vehicle for providing and equalizing opportunity (Hochschild and Scovronick 2003). The US is followed by the other Anglophone countries. The least accessible schooling regimes are in Belgium, Germany, and possibly France (for which we lack good data). Few features of schooling in these countries ease newcomers' path. Rather surprisingly given recent electoral hostility to immigrants, Switzerland ranks in the middle.

We turn finally to the third component of the mapping project -- newcomers' schooling achievement. With it, we can analyze the relationship between "inputs" (immigration regimes), intermediaries (the schooling regime), and "outputs" (immigrants' test scores) - and thus evaluate countries' overall response to immigration.

\section{School Achievement}

One can measure and compare achievement levels in several ways. To do so, we use data from the 2000, 2003, and 2006 PISA initiatives. [For an explanation of PISA, see (Organisation for Economic Co-operation and Development 2007b); on its impact, see (Grek 2009)]. The analyses in the next few paragraphs explicate figures $4 a, 4 b$, and $4 c$, which show comparable results for the three PISA years:

Figure 4a: Combined Reading, Math, and Science Performance in PISA 2000, by Country and Immigration Status 


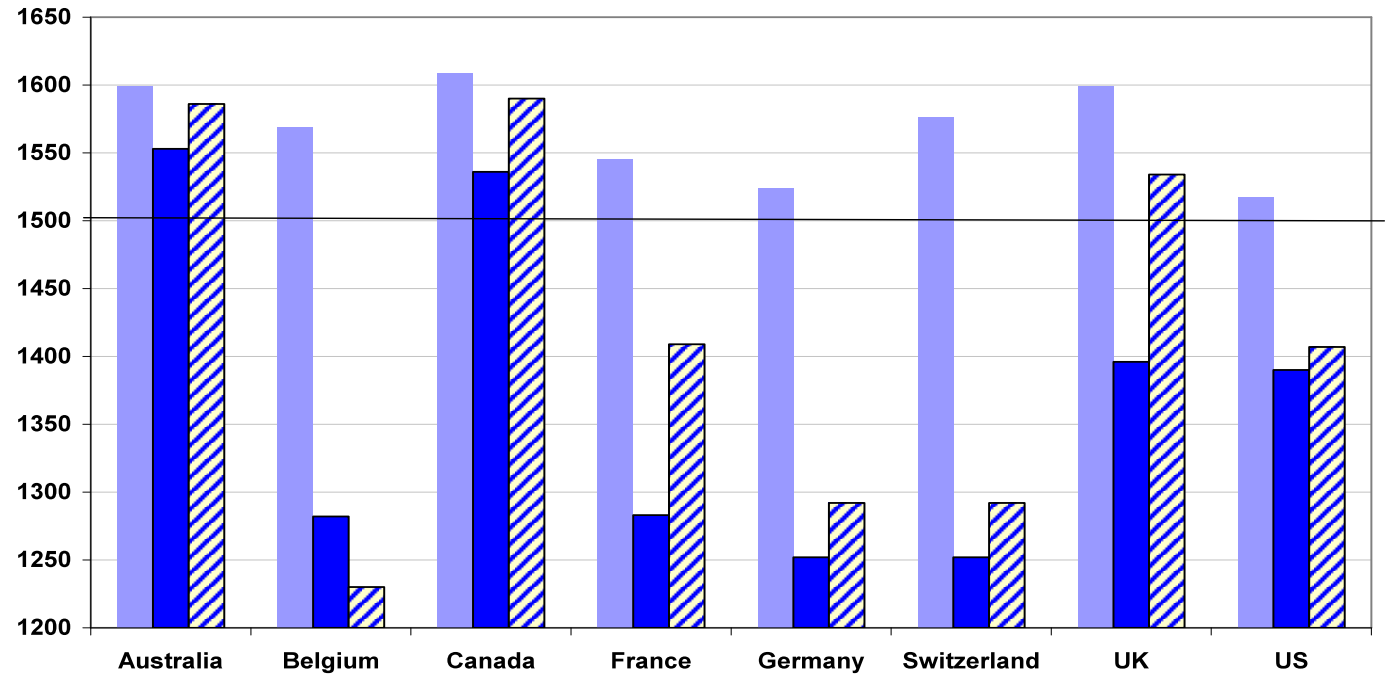

Figure 4b: Combined Reading, Math, and Science Performance in PISA 2003, by Country and Immigration Status

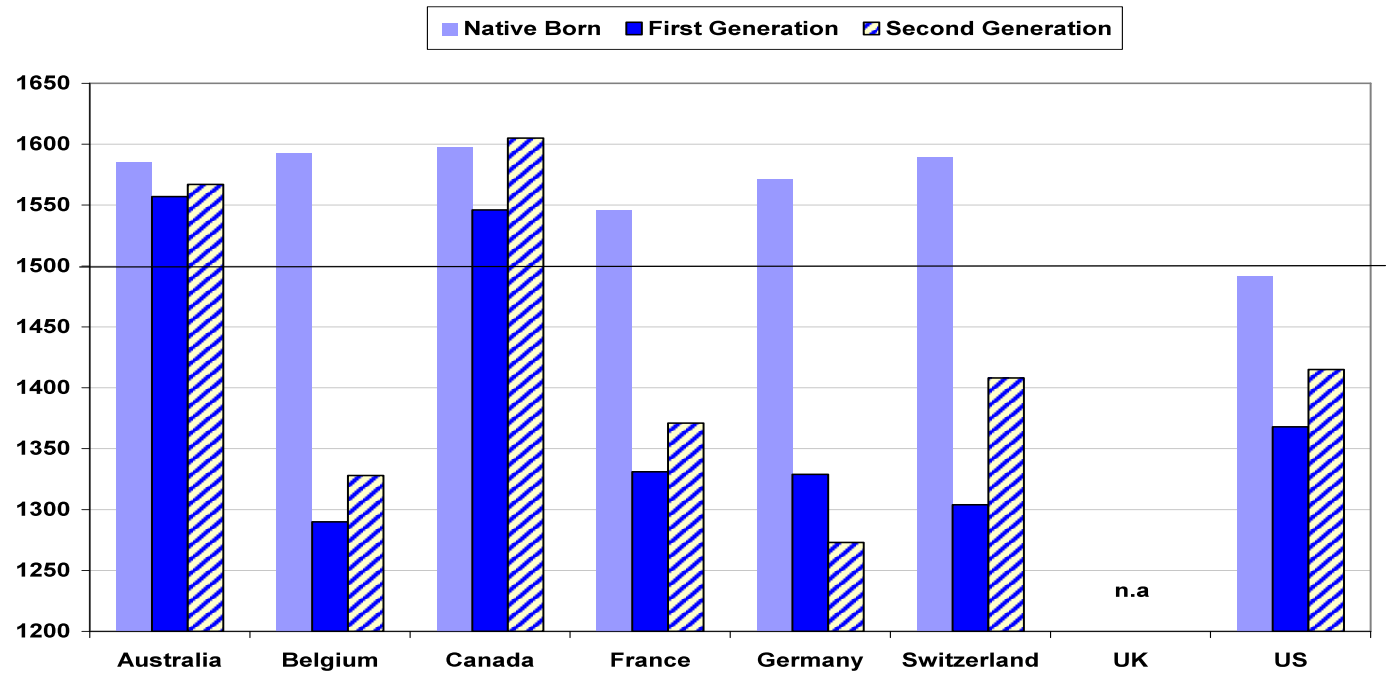

Figure 4c: Combined Reading, Math, and Science Performance in PISA 2006, by Country and Immigration Status 


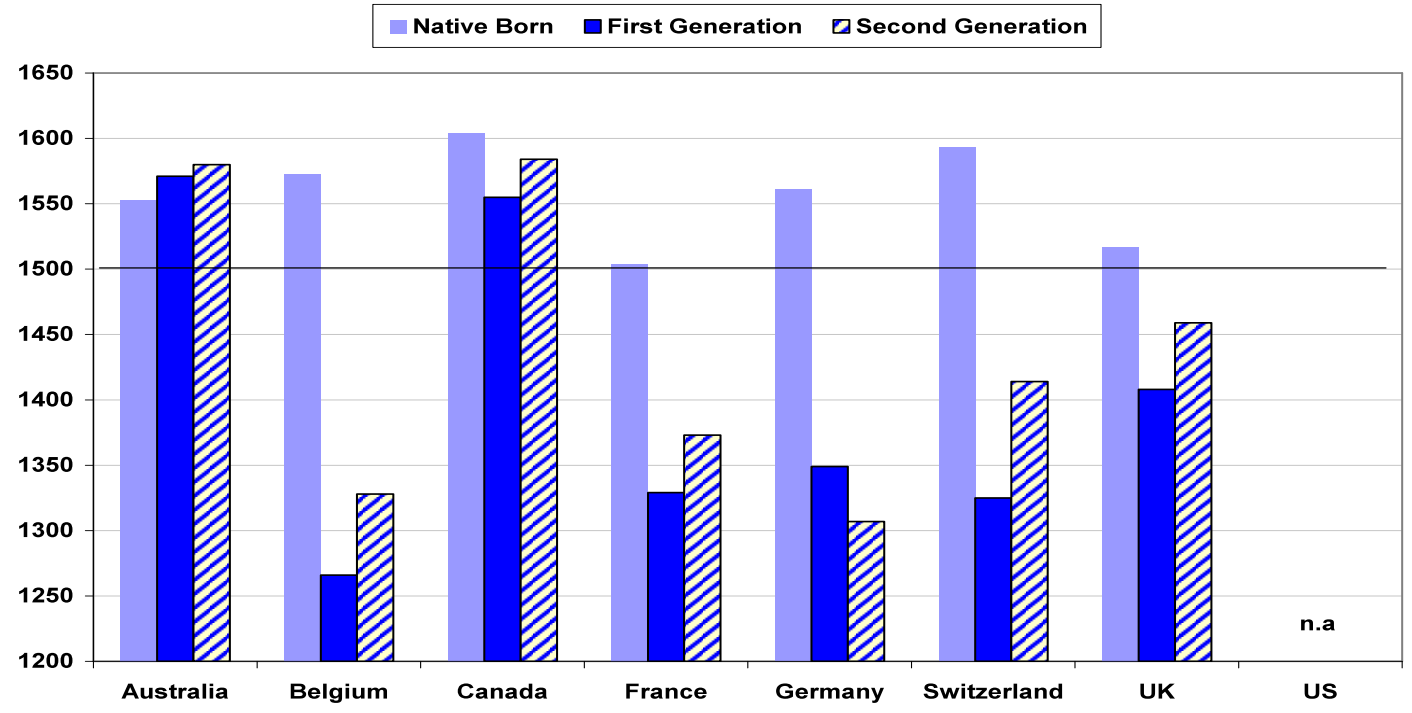

PISA is designed so that the average score on each test is 500 points, and two-thirds of the test takers score between 400 and 600 points. The panels of figure 4 sum test scores for reading, math, and science for each test year, so that the average score for each year is 1500 points (the dark horizontal line in each figure). Separate scores for each test, by country, year of test, and immigration status are in Appendix A3.

Levels of Achievement: Except in the US, native-born children (the solid light bar) always score at least 1500 points in each year. (Native-born Americans scored 970 on math and science in 2006; reading scores are unavailable.) Native-born Canadians always score the highest; native students in Switzerland, Belgium, and Australia consistently do well. Those in the US and France usually, though not always, score the lowest.

Immigrants (the solid dark bar) in Australia and Canada also always score above 1500 points -- but only once (in the UK in 2006) do immigrants in any other country come close to that level. Conversely, Belgian immigrants never score above 1300, and those in Switzerland, Germany, and France never pass 1350. (Immigrants in the US in 2006 scored a respectable 884 on two of the three tests).

Second generation students (the striped bar) do somewhat better than foreign-born students, as one would hope if assimilation is occurring. The children of immigrants in Australia and Canada always score above 1550; they scored above 1500 in the UK in 2000 but not in any other country or year. Conversely, second generation students scored below 1350 in Belgium and Germany in each test year. (Second generation students in the US in 2006 scored 914 on two of the three tests.)

The data suggest a slight improvement over time in second generation achievement, given that there are no scores below 1300 in 2006, unlike in 2000 or 2003.

Disparity: Test Scores of Native- and Foreign-Borns: The absolute levels of achievement show, to no one's surprise, that native born students score the highest in most cases. A more subtle analysis is needed to show progress, or lack thereof, in newcomers' 
achievement levels. (Appendix table A4 shows the results of these comparisons, derived from Appendix table A3).

Consider first immigrant compared with native-born students. Twenty-two comparisons can be made between immigrants and native-borns, given three test years and data for eight countries in each year (with the exception of the UK in 2003 and the US in 2006). In only six of the 22 comparisons, all in Australia and Canada, is the disparity between native borns and immigrants slight, that is less than 50 points. Conversely, in seven comparisons, the disparity is great - more than 200 points -- and it occasionally reaches 300 points in Switzerland, Germany, and Belgium.

Disparities between native borns and immigrants diminished slightly over the test period in a few countries. Australia, France, and the UK were the most effective, and Canada, Switzerland, and Germany made some progress in reducing the achievement gap between native borns and immigrants. Belgium and the US were ineffective; in two of the three subjects in both countries, disparities increased over the six year period.

Mobility: Test Scores across Immigrant Generations: We cannot literally compare across generations since we lack data linking immigrant parents with their children; we do not even have data to compare young immigrants who arrived a generation ago with young immigrants arriving recently. We can, however, compare immigrant children to the native-born children of immigrants - that is, compare immigrants (the dark bar in each panel of figure 4) and second generation immigrants (the striped bar) at a given point in time. ${ }^{24}$ Greater incorporation in this case is a larger distance between the groups, on the grounds that a child born in a host country should be able to achieve more in school than a child born outside the host country. If the second generation student has test scores as low as or lower than the immigrant student, that is a clear signal that the host country is not effectively incorporating even children born on its soil.

As above, 22 comparisons are available between immigrant and secondgeneration students, given three test years and data for eight countries in each year (with the exception of the UK in 2003 and the US in 2006). Only three of the 22 comparisons show a disparity of 100 points or more between second generation students and immigrants - one each in the UK, France, and Switzerland. However, in three comparisons, second generation students score worse than immigrants in that country - a clear signal that mobility is stalled. This dismal result occurs once in Belgium and twice in Germany. In most of the other comparisons, second-generation students score roughly 50 points higher than do their immigrant counterparts; that is a sign of some assimilation, but not of highly successful incorporation.

Judging by these test scores, the second generation made slightly greater gains compared with immigrants in 2000 than in subsequent years, while more scores indicate very little assimilation in 2006 than in either of the previous test years. In five of the eight countries - Australia, Canada, France, Germany, and the UK - second generation students lost ground compared with immigrant students between 2000 and 2006. The US showed a slight improvement across immigrant generations and, surprisingly, Belgium showed a dramatic improvement.

Educational Assimilation: Test Scores of Natives and the Second Generation: Perhaps the most important measure of incorporation is how well native-born children of 
immigrants do compared with native-born children of host country nationals (Simon 2003). This measure enables us to consider how much of an achievement gap remains when one "controls for" immigration status, by comparing two sets of children born in the host country.

Once again, 22 comparisons are available between native-born and secondgeneration students, given three test years and data for eight countries in each year (with the exception of the UK in 2003 and the US in 2006). The comparisons reveal some grounds for optimism. In seven of the 22 comparisons, disparities are relatively small (100 or fewer points) and in two more, second-generation test takers do better than their native born peers. By this measure, second-generation students in Australia and Canada are completely assimilated, those in the UK are doing quite well, and those in the US are assimilating to some degree.

However, the comparisons between native-born and second-generation students also provide grounds for dismay. On seven of the 22 comparisons (all three in Belgium and Germany and one in Switzerland), disparities between natives and the second generation exceeded 200 points, sometimes by a lot. That is as bad as the discrepancy between natives' and immigrants' scores in those countries. Educational assimilation has not taken place in those states.

The assimilation scores suggest both increasing and decreasing assimilation, depending on the country. Over the six year period, Belgium reduced the disparities between native born and second generation the most (it had the longest way to go), while France, the UK, and the US showed some improvement or improvement in some but not all three fields. Disparities in Switzerland and Germany grew.

\section{Arraying Countries by Students' Educational Outcomes}

As we did with immigration regimes (table 2) and educational regimes (table 6), we can now rank the countries through an index of educational incorporation. The components of the index and scoring on each component are in Appendix Table A5; Table 7 provides the results.

Table 7: Scale of Newcomers' Academic Achievement in Selected Countries, 2000 2006

\begin{tabular}{|l|c|c|c|c|}
\hline & $\begin{array}{l}\text { Score on index of } \\
\text { academic } \\
\text { achievement for } \\
\text { newcomers }\end{array}$ & $\begin{array}{l}\text { Number of 3's } \\
\text { (high level of } \\
\text { achievement or } \\
\text { increases in } \\
\text { achievement) }\end{array}$ & $\begin{array}{l}\text { Number of 1's } \\
\text { (low level of } \\
\text { achievement or no } \\
\text { increases in } \\
\text { achievement) }\end{array}$ & $\begin{array}{l}\text { Number of } \\
\text { items for } \\
\text { which the } \\
\text { country could } \\
\text { not be scored }\end{array}$ \\
\hline Australia & 18 & 5 & 2 & 0 \\
\hline Canada & 17 & 4 & 3 & 0 \\
\hline UK & 17 & 2 & 1 & 0 \\
\hline France & 16 & 2 & 2 & 0 \\
\hline US & 15 & 0 & 1 & 0 \\
\hline Belgium & 13 & 2 & 5 & 0 \\
\hline Switzerland & 12 & 1 & 5 & 0 \\
\hline Germany & 10 & 0 & 6 & 0 \\
\hline
\end{tabular}

NOTE: We examined 8 elements on a scale of 1 to 3 , so possible scores range from 8 to 24 . 
A country with missing data for a given element was scored at 2 .

Source: Appendix Table A5.

The three countries most effective in educational incorporation, as judged by test scores, are Anglophone, although none is a stunning success. Belgium has improved considerably from a very unequal starting point, while Switzerland and Germany are failing, at least relative to the other states in this group, to incorporate newcomers educationally.

\section{Comparing Immigration Regimes and Educational Regimes}

We can now bring the strands of the analysis together in order to jointly consider immigration and educational regimes. Having three summary indices permits three sets of comparisons, which provide the basis for our normative conclusions.

Immigration Regimes and Educational Regimes: Combining tables 2 and 6 gives leverage on the question of whether states seek to bring in immigrants with a lot of incorporative resources, to encourage successful incorporation through schooling, or both. Figure 5 shows the eight states' relative positions:

Figure 5: Comparing Immigration Regimes and Educational Regimes

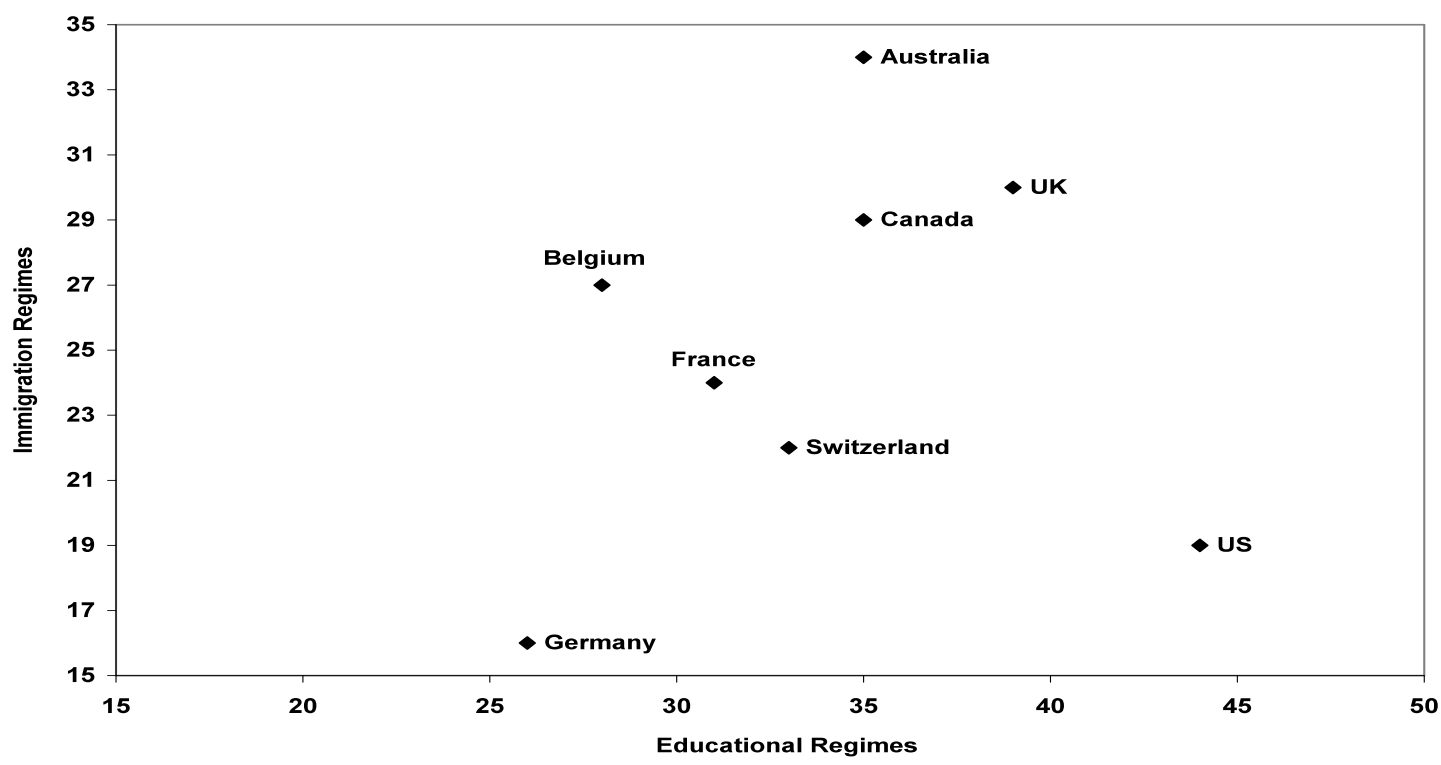

Australia, the UK, Belgium, and Canada seek - in different ways -- to admit immigrants with the capacity to be rapidly incorporated; among those four, the UK stands out for its provision of educational policies to facilitate newcomers' incorporation and Belgium for its relative failure. Conversely, the US and Germany permit (or seek) immigrants for whom incorporation will be difficult, and the two countries differ dramatically in their schooling policies to facilitate it. France and Switzerland lie in the middle on both dimensions. 
The various locations in figure 5 have very different normative qualities. In our view, two countries have attractive policies, albeit quite different from one another. The US accepts people who are deeply disadvantaged and has promulgated schooling policies that encourage their incorporation, at least in theory; the UK also has incorporative educational policies, although it makes its assimilative task easier by seeking immigrants with more social and cultural capital relevant to the host country. Three other countries have less morally compelling policies; Canada, Belgium, and Australia aim to attract high status immigrants and do relatively little to aid young newcomers in school. Germany is the most problematic. It accepts deeply disadvantaged immigrants, but has few policies to encourage their academic success or incorporation. The normative status of France and Switzerland is more ambiguous in this set of comparisons.

Educational Regimes and Academic Achievement: Combining tables 6 and 7 gives leverage on how much states do to enable newcomers' school achievement, and how successfully they do it. Figure 6 shows the results:

\section{Figure 6: Comparing Educational Regimes and Newcomers' Academic Achievement}

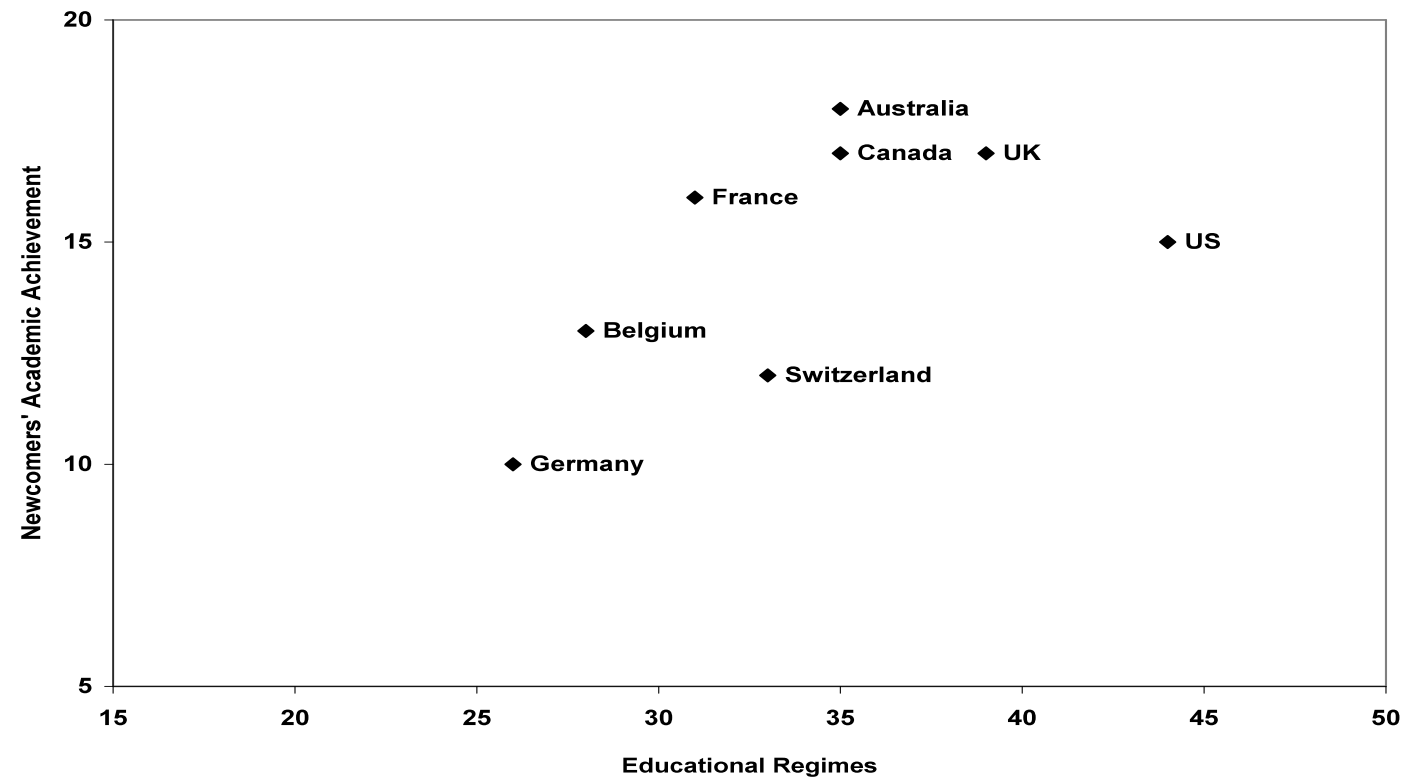

As in the earlier comparison, states differ in their relative success on one or both dimensions. The schooling policies of Canada, Australia, and France do relatively little to assimilate newcomers, but their newcomer students nevertheless have considerable success. The UK and especially the US have more accessible schooling regimes, with high test score results in the UK and a little lower in the US. Switzerland is roughly as accessible than France, but much less successful in schooling outcomes; Belgium, and Germany have neither accessible schooling regimes nor successful newcomer students. 
As before, these results have distinct normative connotations. Germany, Switzerland, and Belgium lend themselves to an accusation of exploiting vulnerable immigrant children. Their policies are not designed to promote newcomers' educational success, and they do not do so. The US and the UK, in contrast, are the most morally attractive; their schooling regimes promote assimilation to a considerable degree, and they are reasonably successful. Australia, Canada, and France, finally, are normatively ambiguous. Their newcomer students can almost be said to succeed at higher levels than their educational policies deserve. That is surely a good thing for these countries and their populations, but it is not especially morally praiseworthy.

Immigration Regimes and Educational Policy: Finally, combining tables 2 and 7 provides the broadest framework for analyzing levels of immigrant incorporation. Figure 7 brings the beginning and end of the process we have been mapping into direct comparison, by relating immigration regimes to schooling outcomes:

\section{Figure 7: Comparing Immigration Regimes and Newcomers' Academic Achievement}

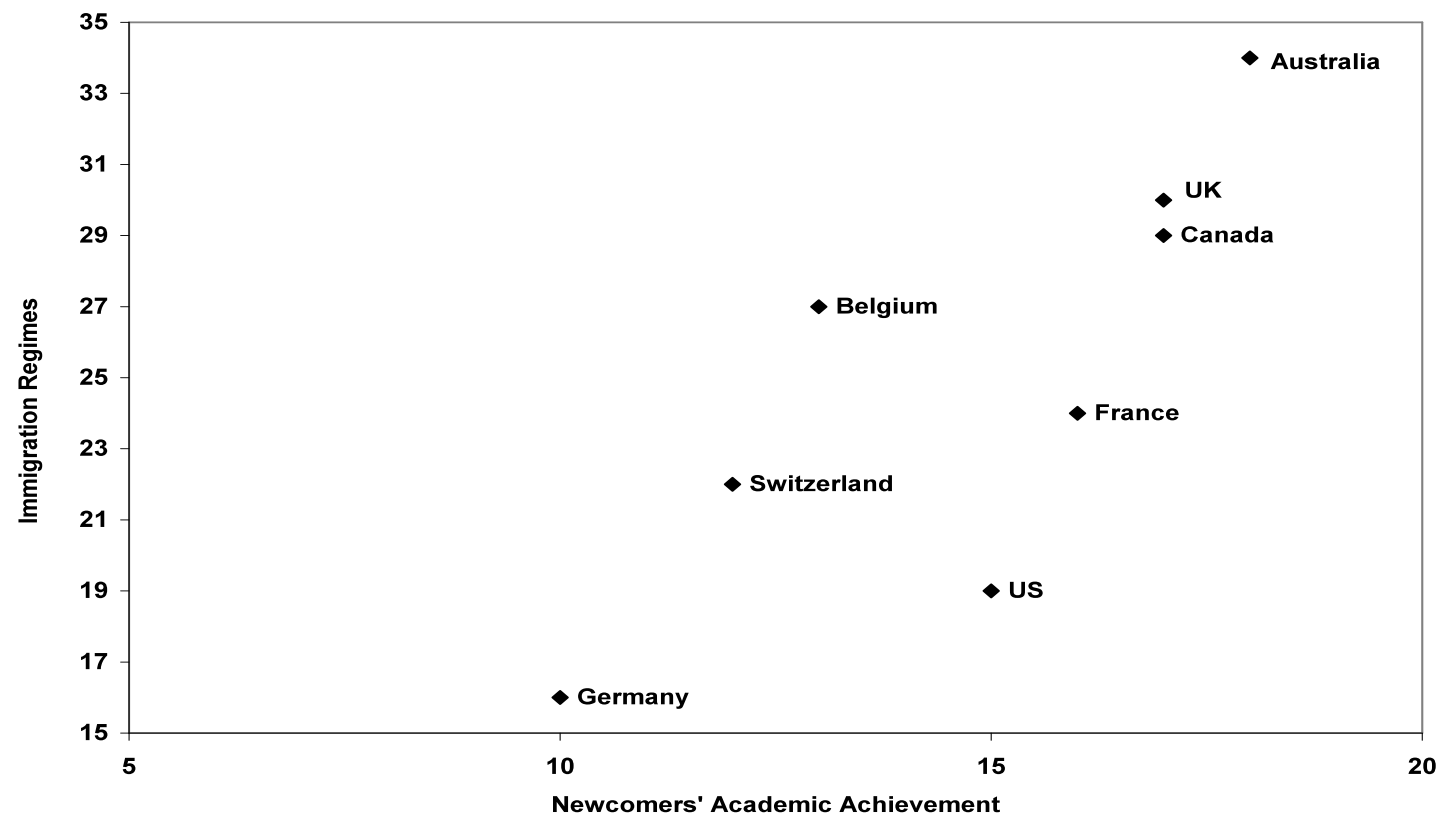

Australia, the UK, and Canada demonstrate the most successful incorporation. Their immigration regimes are designed to bring in immigrants with many resources appropriate to the receiving country, and their young newcomers do in fact achieve at a high level. Switzerland and especially Germany can be said to have gotten what they asked for. They have immigration regimes that encourage migrants with few resources appropriate to the receiving country, and their newcomer students are struggling in school. Belgium is in perhaps the most unfortunate position; its immigration regime is designed to admit migrants with fairly high levels of relevant resources, but newcomer students are 
not achieving at a commensurate level. France and the US are the most interesting and surprising of the eight cases. Both have immigration regimes that permit or encourage immigrants with few resources useful in the host country, but both are producing newcomer students with relatively high levels of achievement. From this vantage point, France and the US can be said to be the most effective, in terms of "value added," of the eight countries.

\section{Conclusion}

Overall, this mapping exercise provides grounds for a several normative as well as empirical judgments about the consequences of migration to wealthy industrialized western states. Low-skilled migration to OECD countries can be thought of as exploitation of people whose only alternative is to remain in deep poverty in their native country, or as the voluntary choice of people eager to improve their lives. For us, the crucial question is the consequence of this type of migration, especially for the young. In some cases, such as Switzerland and Germany, the receiving country seems to be indifferent to or perhaps discriminatory against young migrants, at least in the sense that their academic achievement is low. In other cases, such as France and the US, the receiving country is quite effective, even impressively so, in incorporating the children of low-skilled newcomers through schooling.

In parallel fashion, high-skilled migration to OECD states can be thought of as encouraging a brain drain from countries that badly need the resources that migrants take with them, or as a legitimate opportunity for people with resources to use them to help themselves, their families, and perhaps society at large. Again, for us the crucial question is what happens after migration, especially to the young. The UK, Canada, and Australia show success in educational incorporation, mainly by promulgating policies to encourage those migrants most likely to succeed. Empirically, it is a smart policy; normatively, it does not deserve great praise. Finally, Belgium has apparently the worst of both worlds policies to promote immigrants with high levels of resources, but relative failure to achieve incorporation through schooling.

To return to the opening examples: we conclude that France may have a better immigration regime than Canada, at least for the migrants and perhaps for the world as a whole. That is not what one would infer from media reports of recent events, but it does seem to be what is revealed by combining immigration policies and immigrant policies.

\section{References}

"Immigration and Germany's Elections". 1994. Migration News. 0 (4).

Alba, Richard and Victor Nee. 2003. Remaking the American Mainstream: Assimilation and Contemporary Immigration. Cambridge MA: Harvard University Press.

Allison, Graham. 1969. "Conceptual Models and the Cuban Missile Crisis." American Political Science Review. 63 (3 ): 689-718.

Baldwin, Peter. forthcoming 2009. The Narcissism of Minor Differences: How Unlike Each Other Are America and Europe? New York: Oxford University Press. 
Bauböck, Rainer, ed. 2006. Migration and Citizenship: Legal Status, Rights and Political Participation. Amsterdam, the Netherlands: Amsterdam University Press, IMISCOE Reports.

Baubock, Rainer, Eva Ersboll, Kees Groenendijk, Harald Waldrauch, and CHECK ACCENTS, ed. 2006. Acquisition and Loss of Nationality: Policies and Trends in 15 European States. Vienna, Austria: Austrian Academy of Sciences, Institute for European Integration Research.

Bean, Frank, Susan Brown, Mark Leach, Jim Bachmeier, Leo Chávez, Louis DeSipio, Rubén Rumbaut, Jennifer Lee, and Min Zhou. 2006. How Pathways to Legal Status and Citizenship Relate to Economic Attainment among the Children of Mexican Immigrants Irvine CA: University of California, Irvine; Center for Research on Immigration, Population and Public Policy. (http://www.cri.uci.edu/pdf/PewReport_090506.pdf).

Bloemraad, Irene. 2006. Becoming a Citizen: Incorporating Immigrants and Refugees in the United States and Canada. Berkeley CA: University of California Press.

Burtless, Gary, ed. 1996. Does Money Matter?: The Effect of School Resources on Student Achievement and Adult Succcess. Washington D.C.: Brookings Institution Press.

Cerna, Lucie. 2008. Towards an EU Blue Card? The Proposed Delegation of National High-Skilled Immigration Policies to the EU-Level. Annual Meeting of the International Studies Association, San Francisco CA: March 26-29.

Crul, Maurice and Jens Schneider. 2005. Integration of Turkish Second-generation Men and Women in Germany and the Netherlands: The Impact of Differences in Vocational and Academic Tracking Systems. Amsterdam, the Netherlands: Universieit van Amsterdam, Institute for Migration and Ethnic Studies. (http://www.imes.uva.nl/staff/documents/CrulSchneider2005.pdf).

D'Amato, Gianni. 2009. "Swiss Citizenship: A Municipal Approach to Participation? ." in Bringing Outsiders In: Transatlantic Perspectives on Immigrant Political Incorporation. Jennifer Hochschild and John Mollenkopf, ed. Ithaca NY: Cornell University Press, 63-73.

Entzinger, Han and Renske Biezeveld. 2003. Benchmarking in Immigrant Integration. Rotterdam, Netherlands: Erasmus University Rotterdam, European Research Centre on Migration and Ethnic Relations. (http://ec.europa.eu/justice_home/funding/2004_2007/doc/study_indicators_integr ation.pdf).

Euwals, Rob. 2007. The Labour Market Position of Turkish Immigrants in Germany and the Netherlands: Reason for Migration, Naturalisation and Language Proficiency. Bonn, Germany: Institute for the Study of Labor (IZA).

Grek, Sotiria. 2009. "Governing by Numbers: The PISA 'Effect' in Europe." Journal of Education Policy. 24 (1): 23-37.

Hansen, Randall. 2008. A New Citizenship Regime for the Age of Mobility? Citizenship Requirements in Europe and North America. Washington D.C.: Migration Policy Institute.

Heath, Anthony, Catherine Rothon, and Elina Kilpi. 2008. "The Second Generation in Western Europe: Education, Unemployment, and Occupational Attainment." Annual Review of Sociology. 34 211-35. 
Hedges, Larry and Amy Nowell. 1999. "Changes in the Black-White Gap in Achievement Test Scores." Sociology of Education. 72 (2): 111-35.

Helbling, Marc. 2008. Practicing Citizenship and Heterogeneous Nationhood: Naturalizations in Swiss Municipalities. Amsterdam, the Netherlands: Amsterdam University Press.

Hochschild, Jennifer and Nathan Scovronick. 2003. The American Dream and the Public Schools. New York: Oxford University Press.

Howard, Marc Morje'. 2006. "Comparative Citizenship: An Agenda for Cross-National Research." Perspectives on Politics. 4 (3): 443-55.

International Social Science Programme. various. (http://www.issp.org/).

Kasinitz, Philip, John Mollenkopf, Mary Waters, and Jennifer Holdaway. 2008. Inheriting the City: The Children of Immigrants Come of Age. New York and Cambridge MA: Russell Sage Foundation and Harvard University Press.

Klusmeyer, Douglas and Alexander Aleinikoff, ed. 2002. Citizenship Policies for an Age of Migration. Washington, DC: Carnegie Endowment for International Peace.

Koopmans, Ruud, Paul Statham, Marco Giugni, and Florence Passy, ed. 2005. Contested Citizenship: Immigration and Cultural Diversity in Europe. Minneapolis: University of Minnesota Press.

Lowell, B. Lindsay. 2005. "Policies and Regulations for Managing Skilled International Migration for Work." United Nations, Population Division, Department of Economic and Social Affairs. (http://www.un.org/esa/population/meetings/ittmigdev2005/P03-LLowell.pdf).

Mahnig, Hans and Andreas Wimmer. 2000. "Country-Specific or Convergent? A Typology of Immigrant Policies in Western Europe." Journal of International Migration and Integration 1(2): 177-204.

Mansoor, Ali and Bryce Quillan, ed. 2006. Migration and Remittances: Eastern Europe and the Former Soviet Union. Washington D.C.: World Bank.

Minkenberg, Michael. 2003. "The Politics of Citizenship in the New Republic." West European Politics 26 (4): 219-40.

Organisation for Economic Co-operation and Development. 2001. Knowledge and Skills for Life: First Results from PISA 2000. Paris, France: OECD.

---. 2006a. International Migration Outlook: SOPEMI - 2006 Edition. Paris, France: OECD.

---. 2006b. Where Immigrant Students Succeed - A Comparative Review of Performance and Engagement in PISA 2003. Paris, France: OECD.

---. 2007a. International Migration Data 2007.

(http://www.oecd.org/document/3/0,3343,en_2649_33931_39336771_1_1_1_1,0 $\underline{0 . h t m l)}$.

---. 2007b. PISA 2006 Science Competencies for Tomorrow's World: Volume 1: Analysis. Paris, France: OECD. (http://www.oecd.org/dataoecd/30/17/39703267.pdf).

---. 2007c. PISA 2006 Science Competencies for Tomorrow's World: Volume 2: Data Paris, France: OECD.

---. 2008a. Education at a Glance 2008: OECD Indicators. Paris France: OECD.

---. 2008b. International Migration Outlook: SOPEMI 2007 Edition Paris France: OECD.

---. 2008c. International Migration Outlook: SOPEMI 2008 Edition Paris France: OECD. 
---. 2008d. Profile of Immigrant Populations in the 21st Century: Data from OECD Countries. Paris, France: OECD.

Papademetriou, Demetrios. 2005. The Global Struggle with Illegal Migration: No End in Sight. Washington D.C.: Migration Policy Institute. (http://www.migrationinformation.org/Feature/display.cfm?ID=336).

Papademetriou, Demetrios and Aaron Terrazas. 2009. Immigrants and the Current Economic Crisis: Research Evidence, Policy Challenges, and Implications. Washington D.C.: Migration Policy Institute. (http://www.migrationpolicy.org/pubs/lmi recessionJan09.pdf).

Parsons, Christopher, Ronald Skeldon, Terrie Walmsley, and Alan Winters. 2007. Quantifying International Migration: A Database of Bilateral Migrant Stocks. Washington D.C.: World Bank.

Passel, Jeffrey and D'Vera Cohn. 2008. Trends in Unauthorized Immigration: Undocumented Inflow Now Trails Legal Inflow. Washington D.C.: Pew Hispanic Center.

Peres, Hubert. 2008. Towards the End of National Models for the Integration of Immigrants in Europe? Britain, France, and Spain in Comparative Perspective. Annual Meeting of the American Political Science Association, Boston MA: August 28-31.

Perez, Sofia and Julian Arevalo. 2008. Immigration and (Left) Partisanship in Europe. Annual Meeting of the American Political Science Association, Boston MA: August 28-31.

Schain, Martin. 2008. Immigrant Integration Policy in France and Britain: Evaluating Convergence and Success. annual meeting of the American Political Science Association, Boston MA: August 28-31.

Simon, Patrick. 2003. "France and the Unknown Second Generation: Preliminary Results on Social Mobility." International Migration Review. 37 (4): 1091-119.

Thomson, Mark and Maurice Crul. 2007. "The Second Generation in Europe and the United States: How Is the Transatlantic Debate Relevant for Further Research on the European Second Generation?" Journal of Ethnic and Migration Studies. 33 (7): $1025-41$.

Tichenor, Daniel. 2002. Dividing Lines: The Politics of Immigration Control in America. Princeton NJ: Princeton University Press.

Weil, Patrick. 2001. "Access to Citizenship: A Comparison of Twenty Five Nationality Laws " in Citizenship Policies for an Age of Migration: The Comparative Citizenship Project. T. Alexander Aleinikoff and Douglas Klusmeyer, ed. Washington D.C.: Carnegie Endowment for International Peace, 17-35.

Zanten, Agnes van. 1997. "Schooling Immigrants in France in the 1990s: Success or Failure of the Republican Model of Integration?" Anthropology and Education Quarterly. 28 (3): 351-74.

\section{BIOGRAPHICAL NOTE}

JENNIFER HOCHSCHILD is the Henry LaBarre Jayne Professor of Government, Professor of African and African-American Studies, Faculty of Arts and Sciences at Harvard University. She studies the intersection of American 
politics and political philosophy, particularly racial and ethnic politics and policy, immigration, educational and social policy, and public opinion or political culture. Hochschild is coauthor of The American Dream and the Public Schools and author of Facing Up to the American Dream: Race, Class, and the Soul of the Nation; The New American Dilemma: Liberal Democracy and School Desegregation; and Whats Fair: American Beliefs about Distributive Justice. She coedited Social Policies for Children. Her forthcoming book is tentatively titled Unstable Boundaries: Skin Color, Immigration, and Multiracialism in U.S. Group-based Hierarchy. She was the founding editor of Perspectives on Politics. Correspondence to: Jennifer Hochschild, Department of Government, Harvard University, 1737 Cambridge Street, CGIS Knafel Building 412, Cambridge, MA 02138. [email: hochschild@gov.harvard.edu]

PORSHA CROPPER is a Ph.D. Candidate in Government and Social Policy at Harvard University. She studies issues of class, inequality, social policy, racial and ethnic politics and policy, immigration, and public opinion. Her current work focuses on economic insecurity and risk among middle and working class families and support for governmental social insurance. Correspondence to: Porsha Cropper, Department of Government, Harvard University, 1737 Cambridge Street, CGIS Knafel Building, Cambridge, MA 02138. [email:

pcropper@fas.harvard.edu] 


\section{Appendix Table A1: Elements of Scale of Conditions for Successful Incorporation,}

c. 2005

\begin{tabular}{|c|c|c|c|}
\hline Element & $\begin{array}{l}\text { Highly } \\
\text { favorable } \\
\text { conditions: } \\
3 \text { points }\end{array}$ & $\begin{array}{l}\text { Moderately } \\
\text { favorable } \\
\text { conditions: } \\
2 \text { points }\end{array}$ & $\begin{array}{l}\text { Unfavorable } \\
\text { conditions: } \\
1 \text { point }\end{array}$ \\
\hline $\begin{array}{l}\% \text { foreign borns who are } \\
\text { undocumented }\end{array}$ & $\begin{array}{l}\text { France } \\
\text { Canada } \\
\text { Australia } \\
\end{array}$ & $\begin{array}{l}\text { Belgium } \\
\text { Germany } \\
\text { Switzerland }\end{array}$ & $\begin{array}{l}\text { US } \\
\text { UK }\end{array}$ \\
\hline$\%$ of immigration slots for work & $\begin{array}{l}\text { Switzerland } \\
\text { Germany }\end{array}$ & $\begin{array}{l}\text { UK } \\
\text { Belgium } \\
\text { Australia } \\
\text { France } \\
\end{array}$ & $\begin{array}{l}\text { Canada } \\
\text { US }\end{array}$ \\
\hline $\begin{array}{l}\text { Policy re temporary high-skilled } \\
\text { workers }\end{array}$ & $\begin{array}{l}\text { UK } \\
\text { Australia }\end{array}$ & $\begin{array}{l}\text { France } \\
\text { US } \\
\text { Canada } \\
\end{array}$ & Germany \\
\hline $\begin{array}{l}\text { Policy re permanent high-skilled } \\
\text { workers }\end{array}$ & $\begin{array}{l}\text { Australia } \\
\text { Canada } \\
\text { UK }\end{array}$ & France & $\begin{array}{l}\text { US } \\
\text { Germany }\end{array}$ \\
\hline $\begin{array}{l}\text { Ratio of tertiary education for native- } \\
\text { born vs. foreign-born }\end{array}$ & $\begin{array}{l}\text { Australia } \\
\text { Canada } \\
\text { UK } \\
\end{array}$ & $\begin{array}{l}\text { Switzerland } \\
\text { France }\end{array}$ & $\begin{array}{l}\text { US } \\
\text { Belgium } \\
\text { Germany }\end{array}$ \\
\hline $\begin{array}{l}\text { Ratio of primary education for native- } \\
\text { born vs. foreign-born }\end{array}$ & $\begin{array}{l}\text { Australia } \\
\text { Canada }\end{array}$ & $\begin{array}{l}\text { Belgium } \\
\text { UK }\end{array}$ & $\begin{array}{l}\text { US } \\
\text { Switzerland } \\
\text { France } \\
\text { Germany }\end{array}$ \\
\hline $\begin{array}{l}\text { Ratio of professional jobs for native- } \\
\text { born vs. foreign-born men }\end{array}$ & $\begin{array}{l}\text { Australia } \\
\text { Belgium } \\
\text { Canada } \\
\text { France } \\
\text { UK } \\
\end{array}$ & & $\begin{array}{l}\text { Switzerland } \\
\text { Germany }\end{array}$ \\
\hline $\begin{array}{l}\text { Stock of foreign-born with contextual } \\
\text { knowledge of host country }\end{array}$ & $\begin{array}{l}\text { Australia } \\
\text { Switzerland } \\
\text { Belgium } \\
\text { UK }\end{array}$ & Canada & $\begin{array}{l}\text { France } \\
\text { Germany } \\
\text { US }\end{array}$ \\
\hline $\begin{array}{l}\text { 1995-2005 flow of foreign-born with } \\
\text { contextual knowledge of host country }\end{array}$ & $\begin{array}{l}\text { Australia } \\
\text { Belgium } \\
\text { Switzerland } \\
\text { UK }\end{array}$ & & $\begin{array}{l}\text { France } \\
\text { Germany } \\
\text { US } \\
\text { Canada }\end{array}$ \\
\hline Legal ease of citizenship acquisition & $\begin{array}{l}\text { Belgium } \\
\text { France } \\
\text { UK } \\
\text { US } \\
\text { Canada } \\
\end{array}$ & $\begin{array}{l}\text { Germany } \\
\text { Australia }\end{array}$ & Switzerland \\
\hline Proportion of foreign born (or & Canada & Belgium & Switzerland \\
\hline
\end{tabular}




\begin{tabular}{|l|l|l|l|}
\hline $\begin{array}{l}\text { foreign) who are citizens of host } \\
\text { country }\end{array}$ & Australia & $\begin{array}{l}\text { US } \\
\text { France }\end{array}$ & Germany \\
\hline & Australia & $\begin{array}{l}\text { Belgium } \\
\text { Canada } \\
\text { France } \\
\text { UK }\end{array}$ & $\begin{array}{l}\text { Germany } \\
\text { Switzerland }\end{array}$ \\
\hline
\end{tabular}

Appendix Table A2: Elements of Index of Schooling Regimes that Make Education More or Less Accessible to Newcomers, c. 2005

\begin{tabular}{|c|c|c|c|}
\hline Element & $\begin{array}{l}\text { High (level of } \\
\text { accessibility to } \\
\text { immigrants): } \\
3 \text { points }\end{array}$ & $\begin{array}{l}\text { Medium: } \\
2 \text { points }\end{array}$ & $\begin{array}{l}\text { Low: } \\
1 \text { point }\end{array}$ \\
\hline $\begin{array}{l}\text { Annual spending per } \\
\text { student } \\
\text {--pre-primary }\end{array}$ & US & $\begin{array}{l}\text { UK } \\
\text { Germany }\end{array}$ & $\begin{array}{l}\text { France } \\
\text { Belgium } \\
\text { Switzerland }\end{array}$ \\
\hline --primary & $\begin{array}{l}\text { US } \\
\text { Switzerland }\end{array}$ & $\begin{array}{l}\text { Belgium } \\
\text { UK }\end{array}$ & $\begin{array}{l}\text { Australia } \\
\text { France } \\
\text { Germany }\end{array}$ \\
\hline --secondary & $\begin{array}{l}\text { Switzerland } \\
\text { US }\end{array}$ & $\begin{array}{l}\text { France } \\
\text { Australia }\end{array}$ & $\begin{array}{l}\text { Belgium } \\
\text { Canada } \\
\text { Germany } \\
\text { UK }\end{array}$ \\
\hline $\begin{array}{l}\text { Change in schooling } \\
\text { expenditure 1995-2005 } \\
\text {--highest } \\
\text { absolute level }\end{array}$ & UK & $\begin{array}{l}\text { Canada } \\
\text { Australia } \\
\text { Switzerland }\end{array}$ & $\begin{array}{l}\text { Belgium } \\
\text { France } \\
\text { Germany } \\
\text { US }\end{array}$ \\
\hline --largest increase & $\begin{array}{l}\text { UK } \\
\text { Australia }\end{array}$ & US & $\begin{array}{l}\text { Canada } \\
\text { France } \\
\text { Germany } \\
\text { Switzerland }\end{array}$ \\
\hline $\begin{array}{l}\text { Annual spending per } \\
\text { student relative to GDP } \\
\text {--pre-primary }\end{array}$ & $\begin{array}{l}\text { US } \\
\text { UK }\end{array}$ & $\begin{array}{l}\text { Germany } \\
\text { France } \\
\text { Belgium }\end{array}$ & Switzerland \\
\hline --primary & $\begin{array}{l}\text { Switzerland } \\
\text { US }\end{array}$ & $\begin{array}{l}\text { Belgium } \\
\text { UK }\end{array}$ & $\begin{array}{l}\text { Australia } \\
\text { France } \\
\text { Germany }\end{array}$ \\
\hline --secondary & $\begin{array}{l}\text { Switzerland } \\
\text { France }\end{array}$ & $\begin{array}{l}\text { Australia } \\
\text { Germany } \\
\text { US }\end{array}$ & $\begin{array}{l}\text { Belgium } \\
\text { Canada } \\
\text { UK }\end{array}$ \\
\hline
\end{tabular}




\begin{tabular}{|c|c|c|c|}
\hline First age of selection & $\begin{array}{l}\text { Australia } \\
\text { Canada } \\
\text { UK } \\
\text { US }\end{array}$ & $\begin{array}{l}\text { Belgium } \\
\text { Switzerland }\end{array}$ & Germany \\
\hline $\begin{array}{l}\text { Needed for admittance } \\
\text { to the school } \\
\text {--academic record }\end{array}$ & $\begin{array}{l}\text { Canada } \\
\text { UK } \\
\text { Australia } \\
\text { US } \\
\end{array}$ & Belgium & $\begin{array}{l}\text { Switzerland } \\
\text { Germany }\end{array}$ \\
\hline $\begin{array}{l}\text {--recommendation } \\
\text { of feeder school }\end{array}$ & $\begin{array}{l}\text { US } \\
\text { Belgium } \\
\text { UK }\end{array}$ & $\begin{array}{l}\text { Canada } \\
\text { Australia }\end{array}$ & $\begin{array}{l}\text { Switzerland } \\
\text { Germany }\end{array}$ \\
\hline $\begin{array}{l}\text {-- parents endorse } \\
\text { school philosophy }\end{array}$ & $\begin{array}{l}\text { US } \\
\text { Switzerland }\end{array}$ & $\begin{array}{l}\text { Canada } \\
\text { UK } \\
\text { Germany }\end{array}$ & $\begin{array}{l}\text { Belgium } \\
\text { Australia }\end{array}$ \\
\hline $\begin{array}{l}\text {-- family members } \\
\text { attend the school }\end{array}$ & $\begin{array}{l}\text { Belgium } \\
\text { US } \\
\text { Switzerland }\end{array}$ & $\begin{array}{l}\text { Canada } \\
\text { Germany }\end{array}$ & $\begin{array}{l}\text { Australia } \\
\text { UK }\end{array}$ \\
\hline $\begin{array}{l}\% \text { of students in school } \\
\text { with ability grouping in } \\
\text { all subjects }\end{array}$ & $\begin{array}{l}\text { Australia } \\
\text { UK } \\
\text { US }\end{array}$ & $\begin{array}{l}\text { Belgium } \\
\text { Canada } \\
\text { Germany }\end{array}$ & Switzerland \\
\hline $\begin{array}{l}\text { Breadth of anti- } \\
\text { discrimination law }\end{array}$ & $\begin{array}{l}\text { Canada } \\
\text { France } \\
\text { Germany } \\
\text { UK }\end{array}$ & & $\begin{array}{l}\text { Belgium } \\
\text { Switzerland }\end{array}$ \\
\hline $\begin{array}{l}\text { Stringency of language } \\
\text { policy (focus on } \\
\text { immersion) } \\
\text {-- primary }\end{array}$ & Australia & $\begin{array}{l}\text { Canada } \\
\text { Germany } \\
\text { Switzerland } \\
\text { UK } \\
\end{array}$ & Belgium \\
\hline --lower secondary & Canada & $\begin{array}{l}\text { UK } \\
\text { Switzerland } \\
\text { Australia }\end{array}$ & $\begin{array}{l}\text { Belgium } \\
\text { Germany }\end{array}$ \\
\hline
\end{tabular}

\section{Appendix Table A3: PISA Test Scores, by Country, Subject, Year, and Immigration Status}

Panel

A3.a 2000

\begin{tabular}{|c|c|c|c|c|c|c|c|c|}
\hline Readin & & & Math & & & Science & & \\
\hline & 2. & & 4. & 5. & 6 & 7. & & 9 \\
\hline $\begin{array}{l}\text { Native } \\
\text { born }\end{array}$ & $\begin{array}{l}\text { Immi- } \\
\text { grants }\end{array}$ & $2^{\text {nd }}$ gen. & $\begin{array}{l}\text { Native } \\
\text { born }\end{array}$ & $\begin{array}{l}\text { Immi- } \\
\text { grants }\end{array}$ & $2^{\text {nd }}$ gen. & $\begin{array}{l}\text { Native } \\
\text { born }\end{array}$ & $\begin{array}{l}\text { Immi- } \\
\text { grants }\end{array}$ & $2^{\text {nd }} \mathrm{gen}$. \\
\hline
\end{tabular}




\begin{tabular}{llllllllll} 
Australia & 532 & 513 & 528 & 536 & 526 & 535 & 531 & 514 & 523 \\
Belgium & 522 & 431 & 411 & 536 & 432 & 418 & 511 & 419 & 401 \\
Canada & 538 & 511 & 539 & 536 & 522 & 530 & 535 & 503 & 521 \\
\hline France & 512 & 434 & 471 & 523 & 441 & 487 & 510 & 408 & 451 \\
Germany & 507 & 419 & 432 & 510 & 423 & 437 & 507 & 410 & 423 \\
Switzer- & 514 & 402 & 460 & 548 & 443 & 489 & 514 & 407 & 454 \\
land & 528 & 456 & 510 & 534 & 483 & 505 & 537 & 457 & 519 \\
UK & 511 & 466 & 478 & 500 & 451 & 467 & 506 & 473 & 462
\end{tabular}

\section{Panel 2003
A3.b}

\begin{tabular}{|c|c|c|c|c|c|c|c|c|c|}
\hline & Reading & & & Math & & & Science & & \\
\hline & $\begin{array}{l}10 \\
\text { Native }\end{array}$ & $\begin{array}{l}11 \\
\text { Immi- } \\
\text { grants }\end{array}$ & $\begin{array}{l}12 \\
2^{\text {nd }} \text { gen } .\end{array}$ & $\begin{array}{l}13 \\
\text { Native } \\
\text { born }\end{array}$ & $\begin{array}{l}14 \\
\text { Immi- } \\
\text { grants }\end{array}$ & $\begin{array}{l}15 \\
2^{\text {nd }} \text { gen } .\end{array}$ & $\begin{array}{l}16 \\
\text { Native } \\
\text { born }\end{array}$ & $\begin{array}{l}17 \\
\text { Immi- } \\
\text { grants }\end{array}$ & $\begin{array}{l}18 \\
2^{\text {nd }} \text { gen. }\end{array}$ \\
\hline Australia & 529 & 517 & 525 & 527 & 525 & 522 & 529 & 515 & 520 \\
\hline Belgium & 523 & 407 & 439 & 546 & 437 & 454 & 524 & 416 & 435 \\
\hline Canada & 534 & 515 & 543 & 537 & 530 & 543 & 527 & 501 & 519 \\
\hline France & 505 & 426 & 458 & 520 & 472 & 448 & 521 & 433 & 465 \\
\hline Germany & 517 & 431 & 429 & 525 & 454 & 432 & 529 & 444 & 412 \\
\hline $\begin{array}{l}\text { Switzer- } \\
\text { land }\end{array}$ & 515 & 422 & 462 & 543 & 453 & 484 & 531 & 429 & 462 \\
\hline UK & -- & -- & -- & -- & -- & -- & -- & -- & -- \\
\hline US & 503 & 453 & 481 & 490 & 453 & 468 & 499 & 462 & 466 \\
\hline
\end{tabular}

\section{$\begin{array}{ll}\text { Panel } & 2006 \\ \text { A3.c } & \end{array}$}

Reading

$19 \quad 20$

Native Immiborn grants

$\begin{array}{llllllllll}\text { Australia } & 514 & 514 & 521 & 510 & 530 & 531 & 529 & 527 & 528 \\ \text { Belgium } & 515 & 413 & 434 & 535 & 423 & 451 & 523 & 430 & 443 \\ \text { Canada } & 532 & 512 & 532 & 531 & 524 & 524 & 541 & 519 & 528 \\ \text { France } & 495 & 449 & 459 & 504 & 442 & 458 & 505 & 438 & 456 \\ \text { Germany } & 510 & 440 & 427 & 519 & 454 & 441 & 532 & 455 & 439\end{array}$

Science

Math

$\begin{array}{lllll}22 & 23 & 24 & 25 & 26\end{array}$

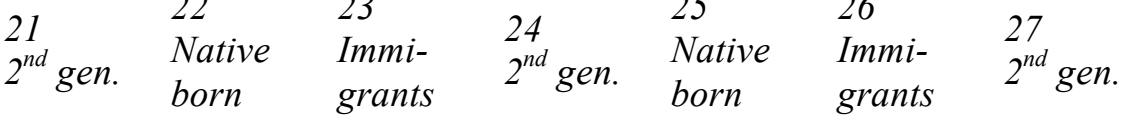

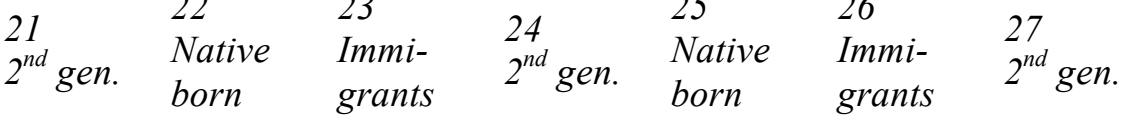




$\begin{array}{llllllllll}\begin{array}{l}\text { Switzer- } \\ \text { land }\end{array} & 515 & 430 & 467 & 547 & 459 & 485 & 531 & 436 & 462 \\ \text { UK } & 499 & 455 & 492 & 499 & 474 & 474 & 519 & 479 & 493 \\ \text { US } & -- & -- & -- & 481 & 444 & 458 & 499 & 442 & 456\end{array}$

Sources: Panel A3.a: (Organisation for Economic Co-operation and Development 2001): table 6.10

Panel A3.b: (Organisation for Economic Co-operation and Development 2006b), tables 2.1a, 2.1b, and 2.1c

panel A3.c: (Organisation for Economic Co-operation and Development 2007c), tables $4.2 \mathrm{a}, 4.2 \mathrm{~d}, 4.2 \mathrm{e}$ 


\section{Appendix Table A4: Comparisons of PISA scores, 2000, 2003, and 2006}

\begin{tabular}{|c|c|c|c|c|c|c|c|c|c|}
\hline \multirow[t]{3}{*}{ Panel } & \multicolumn{9}{|l|}{2000} \\
\hline & \multicolumn{3}{|l|}{ Reading } & \multicolumn{3}{|l|}{ Math } & \multicolumn{3}{|l|}{ Science } \\
\hline & $\begin{array}{l}\text { native- } \\
\text { immigrant }\end{array}$ & $\begin{array}{l}\text { immigrant- } \\
\text { 2nd gen }\end{array}$ & $\begin{array}{l}\text { native - } \\
\text { 2nd gen }\end{array}$ & $\begin{array}{l}\text { native- } \\
\text { immigrant }\end{array}$ & $\begin{array}{l}\text { immigrant- } \\
2 n d \text { gen }\end{array}$ & $\begin{array}{l}\text { native - } \\
\text { 2nd gen }\end{array}$ & $\begin{array}{l}\text { native- } \\
\text { immigrant }\end{array}$ & $\begin{array}{l}\text { immigrant- } \\
\text { 2nd gen }\end{array}$ & $\begin{array}{l}\text { native - } \\
\text { 2nd gen }\end{array}$ \\
\hline Australia & 19 & -15 & 4 & 10 & -9 & 1 & 17 & -9 & 8 \\
\hline Belgium & 91 & 20 & 111 & 104 & 14 & 118 & 92 & 18 & 110 \\
\hline Canada & 27 & -28 & -1 & 14 & -8 & 6 & 32 & -18 & 14 \\
\hline France & 78 & -37 & 41 & 82 & -46 & 36 & 102 & -43 & 59 \\
\hline Germany & 88 & -13 & 75 & 87 & -14 & 73 & 97 & -13 & 84 \\
\hline $\begin{array}{l}\text { Switzer- } \\
\text { land }\end{array}$ & 112 & -58 & 54 & 105 & -46 & 59 & 107 & -47 & 60 \\
\hline UK & 72 & -54 & 18 & 51 & -22 & 29 & 80 & -62 & 18 \\
\hline US & 45 & -12 & 33 & 49 & -16 & 33 & 33 & 11 & 44 \\
\hline \multirow[t]{3}{*}{$\begin{array}{l}\text { Panel } \\
\text { A4.b }\end{array}$} & \multicolumn{9}{|l|}{2003} \\
\hline & \multicolumn{3}{|l|}{ Reading } & \multicolumn{3}{|l|}{ Math } & \multicolumn{3}{|l|}{ Science } \\
\hline & $\begin{array}{l}\text { native- } \\
\text { immigrant }\end{array}$ & $\begin{array}{l}\text { immigrant- } \\
\text { 2nd gen }\end{array}$ & $\begin{array}{l}\text { native - } \\
\text { 2nd gen }\end{array}$ & $\begin{array}{l}\text { native- } \\
\text { immigrant }\end{array}$ & $\begin{array}{l}\text { immigrant- } \\
\text { 2nd gen }\end{array}$ & $\begin{array}{l}\text { native - } \\
\text { 2nd gen }\end{array}$ & $\begin{array}{l}\text { native- } \\
\text { immigrant }\end{array}$ & $\begin{array}{l}\text { immigrant- } \\
\text { 2nd gen }\end{array}$ & $\begin{array}{l}\text { native - } \\
\text { 2nd gen }\end{array}$ \\
\hline Australia & 12 & -8 & 4 & 2 & 3 & 5 & 14 & -5 & 9 \\
\hline Belgium & 116 & -32 & 84 & 109 & -17 & 92 & 108 & -19 & 89 \\
\hline Canada & 19 & -28 & -9 & 7 & -13 & -6 & 26 & -18 & 8 \\
\hline France & 79 & -32 & 47 & 48 & 24 & 72 & 88 & -32 & 56 \\
\hline Germany & 86 & 2 & 88 & 71 & 22 & 93 & 85 & 32 & 117 \\
\hline
\end{tabular}




\begin{tabular}{lccccccccc}
$\begin{array}{l}\text { Switzer- } \\
\text { land }\end{array}$ & 93 & -40 & 53 & 90 & -31 & 59 & 102 & -33 & 69 \\
\hline UK & -- & -- & -- & -- & -- & -- & -- & -- & -- \\
\hline US & 50 & -28 & 22 & 37 & -15 & 22 & 37 & -4 & 33
\end{tabular}

\begin{tabular}{|c|c|c|c|c|c|c|c|c|c|}
\hline \multirow[t]{2}{*}{$\begin{array}{l}\text { Panel } \\
\text { A4.c }\end{array}$} & \multicolumn{9}{|l|}{2006} \\
\hline & $\begin{array}{l}\text { Reading } \\
\text { native- } \\
\text { immigrant }\end{array}$ & $\begin{array}{l}\text { immigrant- } \\
\text { 2nd gen }\end{array}$ & $\begin{array}{l}\text { native - } \\
\text { 2nd gen }\end{array}$ & $\begin{array}{l}\text { Math } \\
\text { native- } \\
\text { immigrant }\end{array}$ & $\begin{array}{l}\text { immigrant- } \\
\text { 2nd gen }\end{array}$ & $\begin{array}{l}\text { native - } \\
\text { 2nd gen }\end{array}$ & $\begin{array}{l}\text { Science } \\
\text { native- } \\
\text { immigrant }\end{array}$ & $\begin{array}{l}\text { immigrant- } \\
\text { 2nd gen }\end{array}$ & $\begin{array}{l}\text { native - } \\
2 n d \text { gen }\end{array}$ \\
\hline Australia & 0 & -7 & -7 & -20 & -1 & -21 & 2 & -1 & 1 \\
\hline Belgium & 102 & -21 & 81 & 112 & -28 & 84 & 93 & -13 & 80 \\
\hline Canada & 20 & -20 & 0 & 7 & 0 & 7 & 22 & -9 & 13 \\
\hline France & 46 & -10 & 36 & 62 & -16 & 46 & 67 & -18 & 49 \\
\hline Germany & 70 & 13 & 83 & 65 & 13 & 78 & 77 & 16 & 93 \\
\hline $\begin{array}{l}\text { Switzer- } \\
\text { land }\end{array}$ & 85 & -37 & 48 & 88 & -26 & 62 & 95 & -26 & 69 \\
\hline UK & 44 & -37 & 7 & 25 & 0 & 25 & 40 & -14 & 26 \\
\hline US & & & & 37 & -14 & 23 & 57 & -14 & 43 \\
\hline
\end{tabular}

Source: see Table A3. 


\section{Appendix Table A5: Elements of Index of Academic Achievement by Newcomers,} PISA, 2000 - 2006

\begin{tabular}{|c|c|c|c|}
\hline Element & $\begin{array}{l}\text { High (level of } \\
\text { achievement by } \\
\text { newcomers): } \\
3 \text { points }\end{array}$ & $\begin{array}{l}\text { Medium: } \\
2 \text { points }\end{array}$ & $\begin{array}{l}\text { Low: } \\
1 \text { point }\end{array}$ \\
\hline $\begin{array}{l}\text { Average achievement } \\
\text { score across } 9 \text { tests } \\
\text {--immigrants }\end{array}$ & $\begin{array}{l}\text { Australia } \\
\text { Canada }\end{array}$ & $\begin{array}{l}\text { UK } \\
\text { US }\end{array}$ & $\begin{array}{l}\text { Germany } \\
\text { France } \\
\text { Switzerland } \\
\text { Belgium }\end{array}$ \\
\hline -- second generation & $\begin{array}{l}\text { Australia } \\
\text { Canada }\end{array}$ & $\begin{array}{l}\text { UK } \\
\text { France } \\
\text { Switzerland } \\
\text { US }\end{array}$ & $\begin{array}{l}\text { Germany } \\
\text { Belgium }\end{array}$ \\
\hline $\begin{array}{l}\text { Disparity between native- } \\
\text { born and immigrants }\end{array}$ & $\begin{array}{l}\text { Australia } \\
\text { Canada }\end{array}$ & $\begin{array}{l}\text { UK } \\
\text { US } \\
\text { France }\end{array}$ & $\begin{array}{l}\text { Germany } \\
\text { Switzerland } \\
\text { Belgium }\end{array}$ \\
\hline $\begin{array}{l}\text { Change in disparity } \\
\text { between native-born and } \\
\text { immigrants, 2000-2006 }\end{array}$ & $\begin{array}{l}\text { Australia } \\
\text { France } \\
\text { UK }\end{array}$ & $\begin{array}{l}\text { Canada } \\
\text { Switzerland } \\
\text { Germany } \\
\end{array}$ & $\begin{array}{l}\text { Belgium } \\
\text { US }\end{array}$ \\
\hline $\begin{array}{l}\text { Mobility between } \\
\text { immigrants and second- } \\
\text { generation }\end{array}$ & $\begin{array}{l}\text { Switzerland } \\
\text { UK } \\
\text { France }\end{array}$ & $\begin{array}{l}\text { US } \\
\text { Belgium } \\
\text { Germany }\end{array}$ & $\begin{array}{l}\text { Australia } \\
\text { Canada }\end{array}$ \\
\hline $\begin{array}{l}\text { Change in mobility } \\
\text { between immigrants and } \\
\text { second-generation, } \\
2000-2006\end{array}$ & Belgium & US & $\begin{array}{l}\text { Australia } \\
\text { Canada } \\
\text { France } \\
\text { Germany } \\
\text { Switzerland } \\
\text { UK }\end{array}$ \\
\hline $\begin{array}{l}\text { Educational assimilation } \\
\text { between immigrants and } \\
\text { second-generation }\end{array}$ & $\begin{array}{l}\text { Australia } \\
\text { Canada }\end{array}$ & $\begin{array}{l}\text { US } \\
\text { UK } \\
\text { France }\end{array}$ & $\begin{array}{l}\text { Switzerland } \\
\text { Belgium } \\
\text { Germany }\end{array}$ \\
\hline $\begin{array}{l}\text { Change in assimilation } \\
\text { between immigrants and } \\
\text { second-generation, } \\
2000-2006\end{array}$ & Belgium & $\begin{array}{l}\text { Australia } \\
\text { France } \\
\text { UK } \\
\text { US }\end{array}$ & $\begin{array}{l}\text { Switzerland } \\
\text { Germany } \\
\text { Canada }\end{array}$ \\
\hline
\end{tabular}

\footnotetext{
${ }^{1}$ Our thanks to Irene Bloemraad, Eamonn Callan, Susanna Loeb, Van Tran, and seminar participants at Harvard and Stanford universities for their excellent suggestions for improving earlier drafts.

2 In a 2003 survey across thirteen western democratic countries, Canadians were most likely to support increased levels of immigration, and least likely to seek reduced levels.
} 
The disparities between Canadians and others were huge (International Social Science Programme various).

3 "Western" is metaphorical, not geographic, since Australia is one of our cases.

${ }^{4}$ The term "regime" implies that countries are making deliberate policy choices with regard to, for example, the kind of immigrants they seek or permit to enter and the way in which they seek to educate children in that country. Of course, any policy is the outcome of political contingencies, and all have unintended consequences. We assume here, nevertheless, that states write laws and regulations to some more or less explicit and recognized purpose (Allison 1969). For a similar but more extended use of “immigration policy regimes," see (Tichenor 2002).

5 (Heath et al. 2008), among others, warn against combining different groups in the overall rubric of "immigrant." As they point out, distinct nationalities have different trajectories of schooling and employment, and different explanations best explain these trajectories. We implicitly concur when we discuss migrants' language skills and contextual knowledge. Nevertheless, we believe that aggregation is warranted for some purposes, such as comparing states' overall immigration regimes and overall schooling outcomes.

${ }^{6}$ We use the sometimes loaded term "assimilation," simply as a synonym for incorporation. The process necessarily involves change in the receiving country as well as change in immigrants and immigrant communities, so we seek to avoid sterile debates over whether "assimilation" implies one-way or two-way adjustment.

7 "Benchmarking in integration is possible, but only in a modest way... Immigrant populations, policy instruments, definitions and statistics are too diverse for this" (Entzinger and Biezeveld 2003). Similarly, "how successfully are... newcomers being integrated? This is a huge topic, on which there is little reliable comparative data" ((Baldwin forthcoming): 97 of June 2008 version).

${ }^{8}$ This definition resembles that of (Alba and Nee 2003) and (Thomson and Crul 2007). In this chapter, we focus only on immigrants understood as individuals. For groups, minimal incorporation would also imply host-country tolerance of the community's religious and cultural commitments, some influence in the political and policy arena, enough of an internal class and prestige structure to permit some group members to be seen as leaders, and the ability to shape a community life that emerges from modes of living in the country of origin.

${ }^{9}$ Thanks to Nolan McCarty for this definition.

${ }^{10}$ Here too we focus on individuals and their family, not on groups. An immigrant group would be better off if the community as a whole improves in its status, wealth, political power, or freedom of expression, even if migration does not help some members. 
${ }^{11}$ One could also define "better" from the perspective of the country of origin or of relatives and the community left behind; we save that consideration for another paper.

${ }^{12}$ We skirt the large literature on whether European, or perhaps OECD, states are converging in their policies on immigration and immigrant integration [e.g. (Mahnig and Wimmer 2000); (Peres 2008); (Schain 2008)]. Our analysis shows that national differences are consequential, but since we are not comparing policies over time we cannot say whether the differences have been narrowing.

${ }^{13}$ A useful caution: "Immigration policy is multi-dimensional and measuring it is a very complex undertaking given that governments can use many different tools to affect the number and type of immigrants entering a country. Some of these tools are relatively easy to measure... [b]ut others... are very hard to gauge.... [P]olicies that fall outside the immigration realm per se [also affect migrant flows]... [T] he same policy might have drastically different consequences in terms of immigration numbers in two different countries," depending on such matters as the robustness of the economy or the generosity of the social welfare system (Perez and Arevalo 2008): 6).

${ }^{14}$ For appropriate cautions on the reliability of these data, especially over time, see (Baldwin forthcoming 2009). In his phrase, "the politics of counting foreigners is curious in Europe" (p. 95 of June 2008 version of ms). (Parsons et al. 2007) provide a more thorough and technical discussion of the difficulties in defining an immigrant.

${ }^{15}$ http://www.oecd.org/dataoecd/7/49/24994376.pdf; http://www.migrationinformation.org/datahub/index.cfm

${ }^{16}$ Unlike in the post World War II era, Switzerland's immigration policy since the 1990s has been based on attracting highly skilled workers. Foreign workers from EU and EFTA countries are granted an easy access to the Swiss labor market, regardless of their level of qualification; ironically, that has increased the presence of highly skilled workers. (www.migration-population.ch).

${ }^{17}$ This simplification is problematic in ways that affect likelihood of incorporation. Perhaps most importantly, since Canada and Australia have had point systems to attract needed skilled workers for several decades, current entrants under the family reunification system tend to be of higher socioeconomic status than in countries with a history of low-skilled guest worker programs, such as the US or Germany. In addition, one analyst describes "asylum seekers to Europe ... [as] a highly selected group: middle class professionals with enough standing at home to have gotten into political trouble and/or the wherewithal to make the arduous and expensive trek to the Schengen borders" ((Baldwin forthcoming 2009): p. 99 of June 2008 version).

${ }^{18}$ In all eight states, temporary workers may bring spouse and children to the receiving country, so their children will be in schools, just like the children of permanent migrants. They are thus part of the student body whose test scores we examine in this chapter. 
${ }^{19} \mathrm{We}$ also include in table 3 the average annual percent of total inflow for sending countries with large stocks in the receiving country, even if those are not among the five dominant recent senders. See, for example, the rows for India and South Africa in the first panel, on Australia.

20 “On October 16, [1994], German voters will choose a new Parliament. The Christian Democratic Union and its sister Bavarian party, the Christian Social Union, have an election platform that acknowledges the enriching role that foreigners provide, but states that 'Germany is not an immigration country' and will not grant automatic citizenship to children of foreign parents born on its territory, or dual citizenship to foreigners" ("Immigration and Germany's Elections" 1994).

${ }^{21}$ Another analysis, however, finds that France and the UK have implemented "more restrictive naturalization policies" since 2000, and that Belgium and Germany have moved in the opposite direction (Baubock et al. 2006). More generally, citizenship laws are being changed frequently in many of the eight states, becoming simultaneously more restrictive in some ways and less so in others (Organisation for Economic Co-operation and Development 2008c), pp. 114- XX).

22 (http://stats.oecd.org/WBOS/index.aspx) for all but Germany; ((Organisation for Economic Co-operation and Development 2006b): 176) for Germany. Data not available for the UK.

${ }^{23}$ Thus we do not report variation on the amount of school choice available to families, the extent and uses of evaluative testing or accountability measures, the level of government that makes decisions for schooling, or the number of educational programs offered to students.

${ }^{24}$ Some analysts resist the term "second generation immigrants" because the people to whom it refers are just as "native-born" as are people whose ancestors lived in the host country for centuries. In principle, we agree; in practice, the phrase "second generation immigrants" is too convenient and too widely-used to be unilaterally jettisoned. 